\title{
Communities of T4-like bacteriophages associated with bacteria in Lake Baikal: diversity and biogeography
}

\author{
Sergey Anatoljevich Potapov ${ }^{\text {Corresp., }}{ }^{1}$, Irina Vasilievna Tikhonova ${ }^{1}$, Andrey Yurjevich Krasnopeev ${ }^{1}$, Maria Yurjevna \\ Suslova $^{1}$, Natalia Albertovna Zhuchenko ${ }^{1}$, Valentin Valerianovich Drucker ${ }^{1}$, Olga Ivanovna Belykh ${ }^{1}$ \\ 1 Limnological Institute Siberian Branch of the Russian Academy of Sciences, Irkutsk, Russia \\ Corresponding Author: Sergey Anatoljevich Potapov \\ Email address: poet1988@list.ru
}

Lake Baikal phage communities are important for lake ecosystem functioning. Here we describe the diversity of T4-bacteriophage associated with the bacterial fraction of filtered water samples collected from the pelagic zone, coastal zone and shallow bays. Although the study of the diversity of phages for the $g 23$ gene has been carried out at Lake Baikal for more than ten years, shallow bays that comprise a significant part of the lake's area have been neglected, and this gene has not previously been studied in the bacterial fraction. Phage communities were probed using amplicon sequencing methods targeting the gene of major capsid protein (g23) and compared phylogenetically across sample locations and with sequences previously retrieved from non-bacterial fractions ( $<0.2 \mathrm{um}$ ) and biofilms (non-fractionated). In this study, we examined six water samples, in which 24 to 74 viral OTUs were obtained. The sequences from shallow bays largely differed from those in the pelagic and coastal samples and formed individual subcluster in the UPGMA tree that was obtained from the comparison of phylogenetic distances of $g 23$ sequence sets from various ecosystems, reflecting differences in viral communities depending on the productivity of various sites of Lake Baikal. According to the RefSeq database, from 58.3 to $73 \%$ of sequences of each sample had cultivated closest relatives belonging to cyanophages. In this study, for phylogenetic analysis, we chose the closest relatives not only from the RefSeq and GenBank NR databases but also from two marine and one freshwater viromes: eutrophic Osaka Bay (Japan), oligotrophic area of the Pacific Ocean (Station ALOHA) and mesotrophic and ancient Lake Biwa (Japan), which allowed us to more fully compare the diversity of marine and freshwater phages. The identity with marine sequences at the amino acid level ranged from 35 to $80 \%$, and with the sequences from the viral fraction and bacterial one from Lake Biwa - from 35.3 to $98 \%$ and from 33.9 to $89.1 \%$, respectively. Therefore, the sequences from marine viromes had a greater difference than those from freshwater viromes, which may indicate a close relationship between freshwater viruses and differences from marine viruses. 
1 Communities of T4-like bacteriophages associated

2 with bacteria in Lake Baikal: diversity and

3 biogeography

4

5

6

7

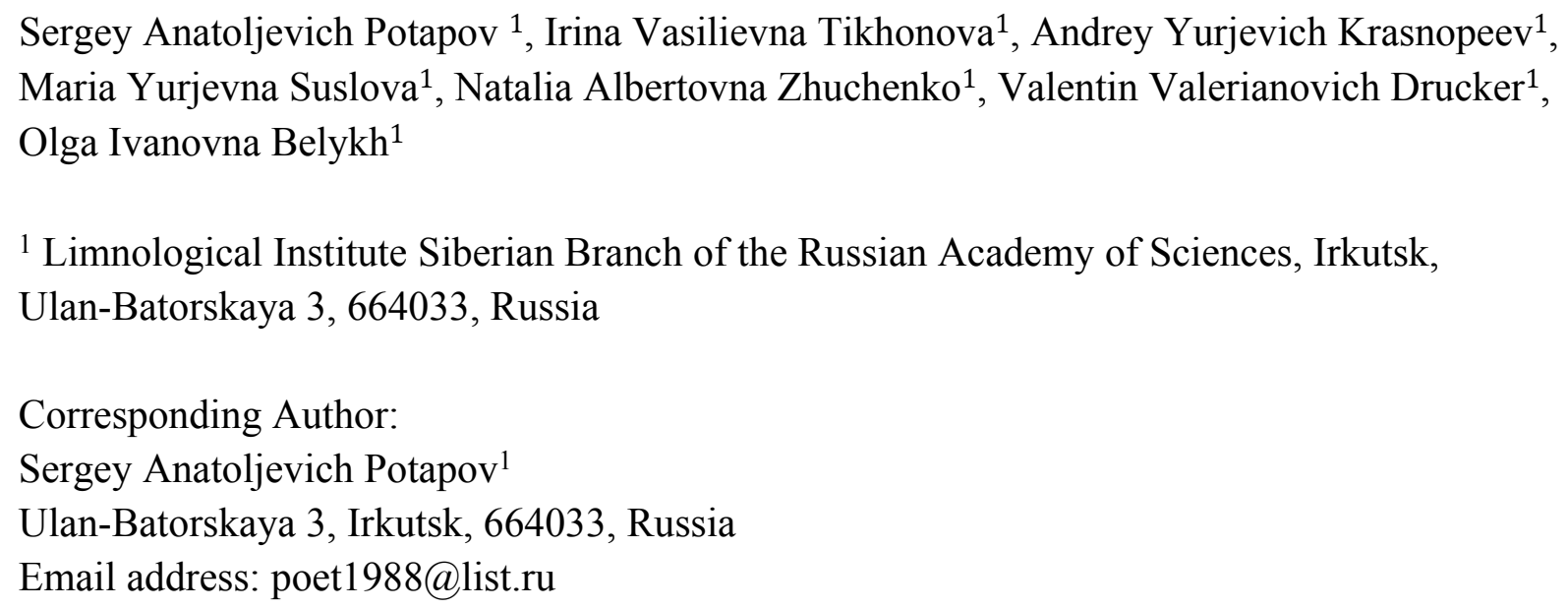

\section{Abstract}

Lake Baikal phage communities are important for lake ecosystem functioning. Here we describe the diversity of T4-bacteriophage associated with the bacterial fraction of filtered water samples collected from the pelagic zone, coastal zone and shallow bays. Although the study of the diversity of phages for the $g 23$ gene has been carried out at Lake Baikal for more than ten years, shallow bays that comprise a significant part of the lake's area have been neglected, and this gene has not previously been studied in the bacterial fraction. Phage communities were probed using amplicon sequencing methods targeting the gene of major capsid protein (g23) and compared phylogenetically across sample locations and with sequences previously retrieved from non-bacterial fractions $(<0.2 \mathrm{um})$ and biofilms (non-fractionated). In this study, we examined six water samples, in which 24 to 74 viral OTUs were obtained. The sequences from shallow bays largely differed from those in the pelagic and coastal samples and formed individual subcluster in the UPGMA tree that was obtained from the comparison of phylogenetic distances of $g 23$ sequence sets from various ecosystems, reflecting differences in viral communities depending on the productivity of various sites of Lake Baikal. According to the RefSeq database, from 58.3 to $73 \%$ of sequences of each sample had cultivated closest relatives belonging to cyanophages. In this study, for phylogenetic analysis, we chose the closest relatives not only from the RefSeq and GenBank NR databases but also from two marine and one freshwater viromes: eutrophic Osaka Bay (Japan), oligotrophic area of the Pacific Ocean (Station ALOHA) and mesotrophic and ancient Lake Biwa (Japan), which allowed us to more fully compare the diversity of marine and freshwater phages. The identity with marine sequences at 
40 the amino acid level ranged from 35 to $80 \%$, and with the sequences from the viral fraction and 41 bacterial one from Lake Biwa - from 35.3 to $98 \%$ and from 33.9 to $89.1 \%$, respectively. 42 Therefore, the sequences from marine viromes had a greater difference than those from 43 freshwater viromes, which may indicate a close relationship between freshwater viruses and 44 differences from marine viruses.

45

46

47

48

49

50

51

52

53

54

55

56

57

58

59

60

61

62

63

64

65

66

67

68

69

70

71

72

73

74

75

76

77

78

79

\section{Introduction}

Viruses are obligate intracellular parasites consisting of a single-stranded or doublestranded RNA or DNA molecule enclosed within a protein capsid; enveloped viruses have an additional membrane envelope (supercapsid). Viruses are distinguished by their high abundance and high genetic diversity (Suttle, 2007), thereby representing an inexhaustible pool for research. To date, according to ICTV Master Species List (ICTV, 2019), 3973 species belong to DNA viruses and 2617 species to RNA viruses, but most of the sequences obtained to date from viromes are known to be "viral dark matter" (Krishnamurthy \& Wang, 2017), and there are much more real biological species of viruses (Gregory et al., 2019). The bulk of the sequences obtained by metagenomic sequencing of DNA-containing viruses in aquatic ecosystems, which can be identified from databases, belong to the order Caudovirales (Cai et al., 2016; Garin-Fernandez et al., 2018; Gong et al., 2018; Taboada et al., 2018; Gregory et al., 2019; Wu et al., 2020). Due to the rapid transformation of viral taxonomy, the order Caudovirales has expanded to 14 families. Among them, the family Myoviridae is the best known and most studied. It includes 8 subfamilies and 153 genera (https://talk.ictvonline.org/taxonomy/).

The family Myoviridae contains DNA phages that are genetically and morphologically similar to the well-studied coliphage T4 (Ackermann \& Krisch, 1997). At the same time, myoviruses can have a relatively wide range of hosts; they can infect hosts belonging to various species or sometimes even various genera of bacteria (Sullivan, Waterbury \& Chisholm, 2003). Due to the lack of universal genes in viruses, signature genes for specific groups are targeted using group-specific primers. The $g 23$ gene fragment encoding major capsid protein is the most reliable marker for the analysis of the biodiversity of T4-like phages of the family Myoviridae (Tetart et al., 2001; Adriaenssens \& Cowan, 2014). Based on the analysis of $g 23$ sequences, T4like phages are divided into several groups: "true" T-evens represented by bacteriophage $\mathrm{T} 4$ and closely related phages infecting enterobacteria (e.g. T2, T6), Pseudo T-evens and Schizo T-evens (phages of the genera Aeromonas, Vibrio, etc.) as well as more distant Exo T-evens (cyano- and pelagiphages, etc.) (Desplats \& Krisch, 2003).

In the aquatic environment, viruses are an important factor in the regulation of the number and structure of microbial communities (Kutter \& Sulakvelidze, 2005). As a result of the viral lysis of bacteria, a significant amount of organic matter does not enter higher trophic levels but is reused by the bacterial community (Suttle, 2007). Viruses are also capable of horizontal gene transfer (Zhang \& Gui, 2018). Moreover, viruses can have auxiliary metabolic genes that 
80 modulate the metabolism of host cells during infection, making phage replication more efficient 81 (Warwick-Dugdale et al., 2019). In freshwater ecosystems such as Lake Biwa (Japan), the 82 percentage of daily bacterial production destroyed by viruses was estimated as high and 83 accounted for $52.7 \pm 16.2 \%$ in the upper layer and $13.6 \pm 5.2 \%$ in the deeper layer (Pradeep Ram 84 et al., 2010). In Lake Pavin (France), the average seasonal contribution from bacteriophages to 85 bacterial lysis reached $16.2 \%$ (Sime-Ngando et al., 2016).

86 This article describes the diversity of T4-like viruses based on the gene of the major 87 capsid protein $(g 23)$ in various ecotopes of Lake Baikal. Previously, a high diversity of 88 planktonic T4-like viruses was detected in the pelagic zone of Lake Baikal, and their difference from bacteriophages of other ecosystems was demonstrated (Butina et al., 2010). Later, this signature gene provided an estimation of the composition of phages in eutrophic Lake Kotokel located close to Lake Baikal, $3 \mathrm{~km}$ from the east coast of the lake, and having a direct water connection with it (Butina et al., 2013). Unifrac analysis has revealed that the viral community in Lake Kotokel is closely related to the phages from Lake Donghu in China characterized by a similar trophic state. Subsequently, we have shown that the sequences of the $g 23$ major capsid protein gene from the eutrophic lakes Kotokel (Russia) and Donghu (China) are rather more similar to the sequences from the shallow Maloye More Strait of Lake Baikal than to the sequences from the pelagic zone of the lake (Potapov et al., 2013). In 2018, using high throughput sequencing for the first time, we studied the diversity of phages in the deep southern basin of Lake Baikal. The array of reads yielded 141 OTUs that differed from other ecosystems and, at the same time, were similar to the sequences from the alpine lakes Bourget and Annecy (Potapov et al., 2018). Comparative study of the $g 23$ gene sequences of phages from biofilms formed on stones and sponges in the littoral zone of the lake (viriobenthos), as well as from its surface microlayer (virioneuston), has revealed that benthic and previously obtained planktonic bacteriophages from the pelagic zone of Lake Baikal form a shared Baikal cluster (Potapov et al., 2020). In general, the communities of T4-like bacteriophages from different ecotopes of Lake Baikal are more similar to each other than to the communities from other ecosystems. They are also grouped depending on the biotope and physicochemical parameters of the habitat.

For lytic phages, including myoviruses, three states of life cycle were described: i) free during extracellular search; ii) located in a certain space with no host, which is, for example, associated with an inert particle; iii) actively infects bacteria (Kutter \& Sulakvelidze, 2005). T4like viruses having strong lytic properties likely experience rapid exchange of intracellular and free phages. For instance, phages T4 and $\lambda$ have latent periods of $20 \mathrm{~min}$ and $50 \mathrm{~min}$, respectively (De Paepe \& Taddei, 2006). However, in natural ecosystems, the latent period can be up to 8 hours in cyanophage (Mruwat et al., 2021) or up to 24 hours in myopelagiphages (Zhao et al., 2013).

The study of a bacterial fraction can reveal the relationship between bacteria and bacteriophages infecting them, this will provide an understanding about the phages that are in the propagation stage. 
119

120

121

122

123

124

125

126

127

128

129

130

131

132

133

134

135

136

137

138

139

140

141

142

143

144

145

146

147

148

149

150

151

152

153

154

155

156

157

158

Currently, the diversity of T4-like phages in the viral fraction (less than 0.4 and $0.2 \mu \mathrm{m}$ ) has been mainly studied (Parvathi, Zhong \& Jacquet, 2012; Goldsmith et al., 2015; Wang et al., 2015; Millard, Pearce \& Zwirglmaier, 2016; Liu, Cai \& Zhang, 2017). Organisms larger than 0.2 or $0.4 \mu \mathrm{m}$ (bacterial fraction) are removed using various methods because it is methodologically more preferable to work with a viral fraction that does not contain bacterial cells. Information about the composition and role of viruses within the microbial fraction is scarce and discussed mainly in metagenomic studies (De Cárcer et al., 2016; Zeigler Allen et al., 2017; Aylward et al., 2017; Palermo et al., 2019; Okazaki et al., 2019; Coutinho et al., 2020). Previously, it was shown that the filtration of samples through filters with a pore size of $0.2 \mu \mathrm{m}$ reduces the number of phages in the filtrate by an average of two-thirds (transmission electron microscopy counting method) (Paul, Jiang \& Rose, 1991). In a later study, the proportion of viruses retained on a 0.2 $\mu \mathrm{m}$ filter did not exceed $15 \%$ of the overall number of virus-like particles (epifluorescence microscopy counting method) (Auguet, Montanié \& Lebaron, 2006).

Currently, the littoral zone of Lake Baikal and its shallow bays with a high recreational load are under pressure from the impact of human activities (Timoshkin et al., 2018). Therefore, it is very important to conduct research during this period. In this study, we have compared the pelagic station extremely detached from the anthropogenic impact, the coastal station located near the settlement and shallow bays having a developed recreational zone. Physicochemical and biological aspects of Lake Baikal are heterogeneous due to the great number of bays and shoals adjacent to the estuaries of the large rivers. The heterogeneity is associated with the compositional features, the growth level, spatial distribution and the nature of seasonal and interannual fluctuations. There are two peaks in the seasonal development of Baikal phytoplankton: spring under-ice peak of diatom algae and summer-autumn bloom of picocyanobacteria (Popovskaya, 2000). Long-term observations revealed that a higher level of phytoplankton growth is typical of the shallow bays of the lake. For example, in Posolsk Sor, the phytoplankton biomass reaches $64 \mathrm{~g} \mathrm{~m}^{3}$, in the pelagic zone, it is less than $1 \mathrm{~g} \mathrm{~m}^{3}$. Based on the specific composition and quantitative characteristics of the blooms of blue-green algae in summer, the shallow bays of the lake are classified as eutrophic water bodies (Popovskaya, 2000).

This study aims to reveal the diversity of phages for the $g 23$ major capsid protein gene in shallow bays, at the coastal area and the pelagic part of Lake Baikal and to analyse the obtained data in terms of regional and global biogeography by comparing them with the sequences obtained previously from Lake Baikal and other ecosystems.

\section{Materials \& Methods}

\section{Sampling sites}

Lake Baikal is the oldest (25 million years), the deepest lake in the world. It is of tectonic origin and is located in the Baikal rift depression. The length of the lake is $636 \mathrm{~km}$; the width in the widest part of the lake opposite the estuary of the Barguzin River reaches $80 \mathrm{~km}$, and in the 
159

160

161

162

163

164

165

166

167

168

169

170

171

172

173

174

175

176

177

178

179

180

181

182

183

184

185

186

187

188

189

190

191

192

193

194

195

196

197

198

narrowest area opposite the delta of the Selenga River - about $25 \mathrm{~km}$. The lake is situated in the northeastern part of Central Asia at an altitude of $455.6 \mathrm{~m}$ above sea level. The area of the lake with islands is $31500 \mathrm{~km}^{2}$, the length of the coastline without islands is approximately $2000 \mathrm{~km}$. The greatest depth of the lake $(1637 \mathrm{~m})$ is recorded in its central basin; the maximum depth in the southern basin is $1432 \mathrm{~m}$, and that in the northern basin is $889 \mathrm{~m}$ (Galaziy, 1993).

Lake Baikal is also the world's largest freshwater body that stores $20 \%$ of the land surface waters. The volume of the lake is $23000 \mathrm{~km}^{3}$. Constant temperature $\left(\sim 4^{\circ} \mathrm{C}\right)$ below the thermocline throughout the year is one of the main hydrophysical characteristics of the lake. Deep-water renewal does not exceed 19 years (Hohmann et al., 1997). Additionally, hydrochemical characteristics include high levels of dissolved oxygen (more than 80\%) and low concentrations of mineral nitrogen and phosphorus as well as of organic carbon (Khodzher et al., 2018). Geological, geographical and hydrological characteristics of the lake reflect its uniqueness and high endemism of aquatic organisms (Kozhova \& Izmest'eva, 1998).

For this study, we took samples from two shallow bays of Lake Baikal (Mukhor Bay and Posolsk Sor), one coastal zone (near the Turka settlement) and one pelagic zone (in the middle of the Listvyanka settlement-the Tankhoy settlement section). Samples were collected in August 2019. The shallow bay of Posolsk Sor (maximum depth $3.5 \mathrm{~m}$ ) is located on the southeast coast of Lake Baikal, about $20 \mathrm{~km}$ south of the Selenga River delta. Mukhor Bay is one of the warmest and shallowest bays (average depth $5 \mathrm{~m}$ ) located in the Maloye More Strait that is situated between the mainland and Olkhon Island. Both bays warm up well in July and August and are the most visited tourist sites of Lake Baikal.

Coordinates and names of sampling sites are as follows: Mukhor Bay near the Kuchelga River - MK (53.020244 N, 106.753739 E), a centre of Mukhor Bay - MC (53.044278 N, 106.798343 E), Posolsk Sor Bay - Posol_S (51.96556 N, 106.17181 E), a coastal zone near the Turka settlement - Turk (52.9384 N, 108.21304 E), and the central station of the Listvyanka settlement - the Tankhoy settlement section - LT_05, LT_1015 (51.721883 N, 104.993283 E). Figure 1 shows the sampling map.

In the bays and the coastal zone, samples of a $1 \mathrm{~L}$ volume were taken from the water surface using sterile bottles. At the pelagic station, samples of a $500 \mathrm{~mL}$ volume were taken using a Niskin bathometer from depths of $0,5,10$, and $15 \mathrm{~m}$. Thereafter, the $500 \mathrm{~mL}$ samples from the layers of $0,5,10$, and $15 \mathrm{~m}$ were combined, and two integral samples were obtained: 0 to $5 \mathrm{~m}$ and 10 to $15 \mathrm{~m}$.

Cyanobacteria were identified on an Axio Imager M1 microscope (Zeiss, Germany) equipped with HBO $100 \mathrm{~W}$ mercury lamp and AxioCam camera. The identification was carried out according to the manuals (Komárek \& Anagnostidis, 2008; Komárek, 2013).

\section{Figure 1.}

DNA extraction and preparation of amplicons 
199 Water samples (1 liter) from each site (MK, MC, Turk, Posol_S, LT_05, and LT_1015) were 200 filtered through sterile polycarbonate filters with a pore size of $0.2 \mu \mathrm{m}$ (Sartorius, Germany) 201 without using prefilters, and they were frozen on board the research vessel during the 202 expeditions. DNA was extracted by the standard phenol-chloroform method in the laboratory. 203 Briefly, filters from each sample were cut and placed into separate test tubes with $300 \mu 11 \times \mathrm{TE}$ 204 buffer. Then, lysozyme (Thermo Fisher Scientific, USA) was added (final concentration 1 $205 \mathrm{mg} / \mathrm{ml}$ ) and left for $1.5 \mathrm{~h}$ at $37^{\circ} \mathrm{C}$ in a thermostat. After that, proteinase $\mathrm{K}$ (Thermo Fisher 206 Scientific, USA) (final concentration $1 \mathrm{mg} / \mathrm{ml}$ ) and sodium dodecyl sulfate (SDS) were added 207 followed by incubation at $37^{\circ} \mathrm{C}$ for $1.5 \mathrm{~h}$. The next stage was freezing at $-70^{\circ} \mathrm{C}$ for $12 \mathrm{~h}$; after thawing, $500 \mu \mathrm{l}$ of phenol and chloroform, isoamyl alcohol (24:1) were added to the mixture,

209

210

211

212

213

214

215

216

217

218

219

220

221

222

223

224

225

226

227

228

229

230

231

232

233

234

235

236

237 kept for $10 \mathrm{~min}$ and centrifuged for $5 \mathrm{~min}$ at $13400 \mathrm{rpm}$. The supernatant was transferred to a new tube, and the extraction was repeated with chloroform and isoamyl alcohol. Thereafter, 1/10 of the $\mathrm{NaCH}_{3} \mathrm{COO}(3 \mathrm{M})$ volume and 2 volumes of ethanol $(96 \%)$ were added to the extracted supernatant and left overnight at $-20^{\circ} \mathrm{C}$. Then, it was centrifuged for $20 \mathrm{~min}$ at $13400 \mathrm{rpm}$ and washed twice with $70 \%$ ethanol each time for $1 \mathrm{~min}$. The residue was dried and dissolved in 50 $\mu l$ of deionized water. Primers MZIA1bis and MZIA6 were used (Filée et al., 2005). The PCR mixture consisted of the following components: Master mix 2x Taq M (Alkor Bio, Russia), 0.1 $\mu \mathrm{M}$ primers, nuclease-free water, and DNA template. PCRs were performed with the following PCR cycle parameters: denaturation at $95^{\circ} \mathrm{C}$ for $15 \mathrm{~min}, 30$ cycles of denaturation at $95^{\circ} \mathrm{C}$ for 30 $\mathrm{s}$, annealing at $50^{\circ} \mathrm{C}$ for $30 \mathrm{~s}$, extension at $72^{\circ} \mathrm{C}$ for $1 \mathrm{~min}$, and a final extension at $72^{\circ} \mathrm{C}$ for 10 min. DNA was purified from the PCR mixture using a suspension of magnetic particles CleanMag DNA (Evrogen, Russia). Library preparation and sequencing on Illumina MiSeq 2*300 were performed in the "Genomics Core Facility" (ICBFM SB RAS, Novosibirsk, Russia).

\section{Bioinformatic analysis}

Sequence quality analysis was carried out using the FastQC software tool (Andrews, 2010). Trimming was performed using the Trimmomatic v. 0.36 tool (Bolger, Lohse \& Usadel, 2014) with the following parameters: SLIDINGWINDOW:4:20 LEADING:3 TRAILING:3 MINLEN:50. Further processing was performed using the Usearch v. 11.0.667 tool (Edgar, 2010). Paired-end reads were combined using the -fastq_mergepairs command. Then unique sequences (-derep_fulllength) were sorted out. The next step was clustering at the $97 \%$ identity level, UPARSE-OTU algorithm (-cluster_otus) as well as the removal of chimeras, singletons and doubletons. Thus, all six sets of sequences were processed separately. The chosen level was used after the analysis of rarefaction curves. Additionally, we were guided by previous publications (Millard, Pearce \& Zwirglmaier, 2016; He et al., 2017) where the clustering at the $97 \%$ level was also chosen. For further analyses, the primers were removed. The annotation was performed using the online blastp analysis (https://blast.ncbi.nlm.nih.gov/Blast.cgi) with default expected threshold based on the RefSeq (Release 207) and GenBank non-curated (NR) (Release 243) databases. 
238

239

240

241

242

243

244

245

246

247

248

249

250

251

252

253

254

255

256

257

258

259

260

261

262

263

264

265

266

267

268

269

270

271

272

273

274

275

276

277

Nucleotide diversity values were calculated using DNASP v. 6.12 (Rozas et al., 2017). The sequences were aligned by the ClustalW, Mega 7 software (Kumar, Stecher \& Tamura, 2016) with default settings. Each set of the $g 23$ sequences was tested separately. From this study the sequences were analysed individually for each sample based on the resulting OTUs.

The network was built using the QIIME v. 1.9.1 scripts (Caporaso et al., 2010). At the first step, all sets (566 sequences) obtained from lakes Baikal and Kotokel (nucleotide level) were clustered at the 97\% level (pick_otus.py). The second step was the OTU table (make_otu_table.py). Next, two files were created for the network (make_otu_network.py: real_edge_table and real_node_table), which are required for the analysis in Cytoscape v. 3.7.0 (Shannon, 2003).

Nucleotide sequences from this study were translated to amino acid ones using the BioEdit v. 7.0.9.0 program (Hall, 1999). Based on the blastp analysis, the nearest neighbours were selected for phylogenetic analysis. These data were supplemented with the $g 23$ sequences from the sampling site of the Hawaii Ocean Time-series (HOT) program (Luo et al., 2020), Osaka Bay (Japan) (Nishimura et al., 2017) and Lake Biwa (Japan) (Okazaki et al., 2019).

Viromes from Lake Biwa were obtained from epilimnion and hypolimnion and from two fractions (bacterial and viral). Datasets available in the SRA archive were combined by fractions into two metagenomes: 3 (epilimnion) from the bacterial fraction and 12 from the viral fraction. Thereafter, quality filtration using Trimmomatic v.0.36 with the following parameters: SLIDINGWINDOW:4:20 LEADING:3 TRAILING:3, was carried out separately for the viral fraction and the bacterial fraction. Reads were assembled using the metaSPAdes program (Bankevich et al., 2012). The assembled contigs from Lake Biwa and the contigs available for downloading in NCBI, which were obtained from the sampling site of the Hawaii Ocean Timeseries (HOT) program, station ALOHA (PRJNA352737) and Osaka Bay virome (OBV) (PRJDB4437), were translated into CDS using GeneMarkS v. 3.36 (Besemer, 2001). Nucleotide sequences were annotated in DIAMOND (Buchfink, Xie \& Huson, 2014) with the following settings: database - RefSeq, blastx, min-score - 50, more-sensitive. The sequences having less than $60 \%$ amino acid identity with the sequences from the RefSeq database were removed. Short sequences of less than 250 nucleotides were also removed. Clustering of the sequences at the $100 \%$ level using CD-HIT (Li \& Godzik, 2006) allowed us to exclude identical sequences. Then, the sequences were translated into amino acids, and, on their basis, local databases were created for blastp analysis (e-value $10^{-3}$ ) with the studied sequences. For each set, the search was carried out independently. Unique sequences that were assigned as the closest relatives were included in the phylogenetic analysis. Each sequence was manually checked for the length and $g 23$ gene. Amino acids were aligned in the Mega 7 software using the ClustalW algorithm. A phylogenetic tree was constructed through Bayesian analysis using the MrBayes software (v. 3.2.6) (Huelsenbeck \& Ronquist, 2001). Two independent Markov chain Monte Carlo (MCMC) analyses were launched for 25 million generations with $25 \%$ burn-in (rejection of initial generations) and four chains (one cold and three hot ones), amino acid model (Blosum). Analysis was completed with an average standard deviation of split frequencies: 0.02 ; parameter potential 
278 scale reduction factor (PSRF+) was 1.000. All calculations were performed on HPC-cluster

279 “Akademik V.M. Matrosov" ("Irkutsk Supercomputer Center of SB RAS, http://hpc.icc.ru").

280 To assess the $\beta$-diversity of the sequences, Unweighted Pair Group Method with

281 Arithmetic Mean (UPGMA) (Sneath \& Sokal, 1973) was performed. The datasets were taken

282 from those available in the GenBank NR database. Based on the amino acid sequences, the

283 distance matrix was obtained through the unweighted UniFrac metric (multiple sequence

284 alignment - ClustalW, model - Blosum62, normalized=TRUE) followed by a hierarchical cluster

285 analysis (hclust) (Murtagh, 1992) method "average" (=UPGMA) using phyloseq (v. 1.21.0),

286 vegan (v. 2.5-7) and phangorn (v. 2.2.0) packages implemented in the R software (v. 3.2.4).

287 The raw sequencing data were deposited in the Sequence Read Archive (SRA) of the

288 National Center for Biotechnology Information (NCBI) under the project accession number

289 PRJNA770749; all 250 g23 sequences (OTUs) were deposited in GenBank NR under accession

290 numbers MW690662 - MW690911.

291

292

293

294

295

296

297

298

299

300

301

302

303

304

305

306

307

308

309

310

311

\section{Water Chemistry Analysis}

Chlorophyll $a$ concentration was determined as described previously (Bondarenko et al., 2019).

Total phosphorus content was determined using a KFK-2 photoelectric colorimeter (ZOMZ,

Zagorskii optiko-mekhanicheskii zavod [Zagorskii optical mechanics factory], Russia) after

persulfate oxidation. Total nitrogen concentration was determined by persulfate oxidation in an alkaline medium according to R. G. Wetzel \& G. E . Likens (Wetzel \& Likens, 2000) using a

PE-5300VI spectrophotometer (Ekroskhim (the former "Ekohim"), Russia).

\section{Results}

\section{Microscopy}

Microscopy of the water samples from the coastal station and the pelagic station (LT_05, LT_1015 and Turk) revealed that picoplanktonic cyanobacteria of Synechococcus/Cyanobium cluster predominated in water; the species of the genus Dolichospermum prevailed in the water sample from Mukhor Bay (MK and MC), and Gloeotrichia echinulata dominated plankton from Posolsk Sor (Posol_S).

\section{Environmental parameters}

According to the indicators given in the table, the productivity of shallow bays corresponds to the mesotrophic status, and the productivity of the waters of the pelagic station and coastal station corresponds to the oligotrophic status according to G. E. Likens (Likens,

312 1975). Table 1 shows the results of the physicochemical analysis. Hydrochemical indicators and 313 chlorophyll $a$ concentration are among the range of values observed in summer in Lake Baikal

314 (Belykh et al., 2007; Khodzher et al., 2018).

315

316

Table 1

317 
324

325

326

327

328

329

330

331

332

333

334

335

336

337

338

339

340

341

342

343

344

345

346

347

348

349

350

351

352

353

354

355

356

357

\section{Analysis of $\mathbf{g} 23$ sequences}

Overall, we obtained 250 representative viral sequences (OTU) of the $g 23$ gene fragment based on the $97 \%$ clustering. The lengths of the sequences at the nucleotide level, taking into account the primers, ranged from 355 to 547 nucleotides (average length 439 nucleotides). The main data obtained from processing during the preparation of sequences are shown in supplementary Table 1.

\section{Nucleotide diversity of the $\mathbf{g} \mathbf{2 3}$ gene fragment}

To assess alpha diversity, we conducted a comparative analysis of sequences based on nucleotides (nucleotide diversity, $\pi$ ) (Table 2). In addition to the sequences from this study, the sequences were taken from various sources available in the NCBI database. Based on microdiversity data, among the sequences obtained in this study, Posol_S is the least diverse g23 community in Lake Baikal, and MK is the most diverse one. In contrast, the sequences from the polar Lake Limnopolar, dairy water (Ireland) and Lake Baikal (LS, 2D4) were distinguished by a larger nucleotide diversity.

\section{Table 2}

\section{Blast analysis of the $g 23$ gene (amino acid level)}

Among the cultivated bacteriophages, the highest identity is at amino acid level (from 64.4 to $77.9 \%$ ), and the minimum e-value was with cyanophages: Synechococcus phage SSSM7, Synechococcus phage S-SM2, Synechococcus phage Bellamy, and Synechococcus phage S-CAM1. The bulk of the sequences were annotated as belonging to cyanophages (58.3 to $73 \%)$. A summary of the identified cultivated closest relatives can be found in supplementary Table 2.

Pelagibacter phage HTVC008M was also dominant among the closest relatives (34 to $70.1 \%$ amino acid identity) in terms of the frequency of occurrence: $\mathrm{MK}-13.7 \%, \mathrm{MC}-29.2 \%$, Turk-20\%, Posol_S - 10.8\%,LT_05-16.7\%, and LT_1015-14.3\%.

Moreover, Serratia phage BF (YP_009599751) with identity of 65.8 to $68 \%$, Agrobacterium phage Atu_ph07 (YP_009611880) with identity of 63.7\%, Caulobacter phage Cr30 (YP_009098938) with identity of 58.8 to 61.5\%, Sinorhizobium phage phiN3 (YP_009212304) with identity of 34.8 to $62.34 \%$, and Acidovorax phage ACP17 (YP_009609699) with identity of 56.9\% were among the closest relatives. There were no sequences with $100 \%$ identity with the studied sequences among the cultivated closest relatives.

The protein sequences had uncultivated relatives from various ecosystems (Table 3), and most relatives from the GenBank database were similar to the Baikal sequences that had been previously obtained from biofilms (from 19.6 to $28.6 \%$; identity from 67.9 to $100 \%$ ) and the pelagic zone (from 6.8 to $30 \%$; identity from $75.2 \%$ to $100 \%$ ) of Lake Baikal. The largest number of the closest relatives for samples LT_05, LT_1015 and Turk was from lakes Bourget and Annecy (from 10.8 to $25.7 \%$; identity from 83.9 to $100 \%$ ). An interesting result is the 
358

359

360

361

362

363

364

365

366

367

368

369

370

371

372

373

374

375

376

377

378

379

380

381

382

383

384

385

386

387

388

389

390

391

392

393

394

395

396

397

identity of a large number of sequences from shallow eutrophic bays (MK, MC and Posol_S) with sequences from wetland sediments (from 18.9 to $25.5 \%$; identity from 59.4 to $97.9 \%$ ) (Li et al., 2018), whereas pelagic representatives from samples Turk, LT_05 and LT_1015 had only from 2.8 to $3.3 \%$ of similar sequences with sequences from wetland sediments.

Among uncultivated closest relatives, two sequences from other ecosystems were identified with 100\% identity: from wetland water (BAL45773), Posol_S-Otu35, and Lake Annecy (AHU87275), LT_05-Otu22 and LT_1015-Otu25.

In marine viromes, 34 (HOT) and $11(\mathrm{OBV})$ g23 gene sequences that were the closest relatives for our OTUs were detected. The identity with the sequences from HOT varied from $36.2 \%$ to $79.8 \%$; the highest identity of the amino acid sequence from the HOT201114979 contig corresponded to the sequence from the shallow Posolsk Sor Bay (Posol_S-Otu58). The Baikal sequences, LT_05-Otu31 and LT_1015-Otu29, were closely related to sequences OBV (from $35.1 \%$ to $77.3 \%$ ), with the highest identity of the amino acid sequence from OBV-Vallcontig_N000719. The coverage for all sequences was 100\%. Based on blastp analysis, HOT201114979 had Escherichia phage 121Q as the closest relative with an identity of $65.7 \%$ and coverage of 95\%; for OBV-Vall-contig_N000719, the closest relative was Synechococcus phage S-CAM1 with the identity of $96.2 \%$ and $100 \%$ coverage.

The identity of the $g 23$ sequences from the viral fraction of Lake Biwa with the sequences from this study ranged from 35.3 to $98 \%$, and the coverage - from 88 to $100 \%$. Overall, eight unique sequences were identified, which were the closest relatives. The highest identity was with the MK-Otu49 sequence and a fragment from the Node_13864 contig. In the bacterial fraction from Lake Biwa, 18 sequences were detected with the identity ranging from 33.9 to $89.1 \%$ and the coverage from 75 to $100 \%$. The highest identity was with the Node 42706 fragment and the Posol_S-Otu49 sequence. The most identical g23 fragments in the RefSeq database (blastp analysis) belonged to Pelagibacter phage HTVC008M (YP_007517957), the Node_13864 contig (identity 61.3\% and coverage 99\% ) and Escherichia phage 121Q Node_42706 (identity $60.1 \%$ and coverage 100\%).

\section{Table 3}

\section{Phylogenetic analysis}

Phylogenetic analysis of the amino acid $g 23$ sequences with the cultivated representative T4-like viruses of the family Myoviridae and with the sequences from various natural sources revealed that the sequences from this study were mixed in the tree, and $46.4 \%$ of them had $<90 \%$ amino acid sequence identity with the $g 23$ sequences from the Refseq and GenBank NR 
398

399

400

401

402

403

404

405

406

407

408

409

410

411

412

413

414

415

416

417

418

419

420

421

422

423

424

425

426

427

428

429

430

431

432

433

434

435

436

databases (Fig. 2). Furthermore, 19 clusters (except for groups T-, Pseudo T- and Schizo Tevents) were obtained. Only the sequences from Posol_S formed five monophyletic groups consisting of two or three OTUs. The bulk of the clusters contained the $g 23$ sequences of phages from natural sources, whose hosts are still unknown because there are no cultivated representatives and, hence, the confirmation of phylogenetic affiliation.

Most sequences from this study were similar to the sequences from freshwater ecosystems. None of the sequences was included in groups T-, Pseudo T- and Schizo T-events. Twelve sequences from this study were included in group Exo T-evens containing cultivated cyanophages and the HTVC008M pelagiphages. Also, this group included most of the $g 23$ sequences from viromes $(94.4 \%)$.

In addition to the sequences from marine viromes, the cluster with $100 \%$ support included one sequence from the uncultivated marine bacteriophage (ABV27494) and, based on blastp analysis, it had the maximum identity of $75 \%$ with one OTU from the Turk sample (Turk_OTU-10).

\section{Figure 2.}

\section{Biogeography of g23 sequences Regional level}

To analyse relationships of the $g 23$ sequences at the local level in the Baikal region, we built the network that included various biotopes in Lake Baikal and plankton of Lake Kotokel (Fig. 3). Based on the analysis, clusters from Lake Kotokel and biofilms of stone substrates, 2D1 and 1D3Tp, of Lake Baikal are remote from other Baikal clusters. These clusters do not have shared OTUs (clustering of nucleotide sequences at 97\% level) with other samples. As mentioned above, the sequences from the eutrophic Lake Kotokel were more similar to the sequences from Lake Donghu (China) than to the sequences from Lake Baikal (Butina et al., 2013). Sequences from the biofilm samples, 1D3Tp and 2D1, taken in the southern basin of Lake Baikal from depths of 9 and $36 \mathrm{~m}$, which consisted mainly of cyanobacteria, formed separate clusters in the tree (Potapov et al., 2020).

Samples MK and MC from Mukhor Bay (Maloye More Strait, the west coast) taken at nearby stations with similar hydrochemical and hydrophysical parameters are close to each other and have more shared OTUs than with sample Posol_S taken from Posolsk Sor Bay on the east coast of the lake.

Samples from the coastal site (Turk) and the pelagic station (LT_05 and LT_1015) cluster together and have more shared OTUs with the sequences from the pelagic water (BSOTU).

Peer] reviewing PDF | (2021:07:63663:2:0:NEW 2 Dec 2021) 
437 Samples LT_05 and LT_1015 have more similar OTUs (ten shared OTUs) with previously 438 obtained pelagic samples BSOTU, S0508 (southern basin) and N0508 (northern basin) than with 439 samples from the shallow bays, MC and MK (three shared OTUs), the coastal site, Turk (six 440 shared OTUs), and biofilms, 2D1, 1D3Tp, 2D2, 2D4, 2a, LS, and Neuston (seven shared OTUs).

441

442

443

444

445

446

447

448

449

450

451

452

453

454

455

456

457

458

459

460

461

462

463

464

465

466

467

468

469

470

471

472

473

474

475

\section{Figure 3.}

\section{Global level}

For comparative biogeographical analysis, we selected sequences available in the GenBank NR database (Table 4). All of them were obtained using primers MZIA1bis and MZIA6. The geography of the samples in the databases covers a wide range of climate zones and habitats, ensuring a rather large-scale analysis of phages for the $g 23$ gene fragment. Sampling sites are shown in Figure 4.

\section{Table 4}

\section{Figure 4.}

The $g 23$ sequences in this study and those represented in the GenBank NR database formed groups on the dendrogram: marine, Baikal cluster, Baikal subcluster, soil, and sediments (Fig. 5).

LT_05 and LT_1015, sequences from the samples collected at the central station of the Listvyanka settlement - the Tankhoy settlement section, layer from $0+5 \mathrm{~m}$ and from $10+15 \mathrm{~m}$, are located closer to the site with the sequences from sample Turk as mentioned above, which is due to the mixing with pelagic waters. LT_05, LT_1015 and Turk form a shared cluster together with the sequences previously obtained from the pelagic zone of Lake Baikal (BSOTU) (Potapov et al., 2018). Three samples from shallow Baikal bays (MK, MC and Posol_S) group together, confirming clustering by the similar trophic conditions within the Baikal group.

\section{Figure 5.}

The sequences from biofilms inhabiting stones (LS, 2a, 2D1, and 1D3Tp), neuston and sponges (2D2 and 2D4) (Potapov et al., 2020) form a shared cluster with planktonic g23 
476 sequences from the pelagic zone of the southern and northern basins of Lake Baikal. Samples

477 from Lake East, Lake Donghu and Kongsfjorden also form a shared cluster.

478 The greatest identity of the Baikal $g 23$ is observed with the sample from the subalpine lakes

479 Bourget (oligo-mesotrophic) and Annecy (oligotrophic) (Zhong \& Jacquet, 2014), which we also 480 previously indicated in our study (Potapov et al., 2018).

481 The sequences from the Arctic proglacial lakes and Lake Limnopolar are closer to the sequences

482 from the dairy water (Ireland) and wetland water of China.

483

\section{Discussion}

485

486

487

488

489

490

491

492

493

494

495

496

497

498

499

500

501

502

503

504

505

506

507

508

509

510

511

512

513

514

515
Here, we studied bacteriophages associated with bacteria in a fraction greater than $0.2 \mu \mathrm{m}$ from shallow bays, coastal zone and pelagic zone of Lake Baikal based on the analysis of the $g 23$ gene. The sampling sites were chosen not only to carry out a comparative analysis in terms of geographical distance but also to reveal the differences in the pools of the $g 23$ sequences selected in separate zones of Lake Baikal with varied trophic states.

The highest concentration of the total phosphorus, total nitrogen and chlorophyll $a$ has been documented in shallow bays, which is expected for Lake Baikal because the maximum rate of formation of organic matter occurs here due to a large number of primary producers (cyanobacteria) (Watanabe \& Drucker, 1999; Belykh \& Sorokovikova, 2003). Temperature, in turn, is an important factor, influencing the growth rate of bacteria and having a significant positive effect on bacterial production (Straškrábová et al., 2005). An increase in temperature stimulates the development of phytoplankton, as well as enhances its photosynthetic activity, and the water body is enriched with dissolved organic matter. Previously, it has been shown that temperature controls the number of viruses, their diversity and the activity of hosts reviewed in (Danovaro et al., 2011).

The $\mathrm{pH}$ level is slightly shifted to the alkaline side, which is typical for the waters of Lake Baikal. According to long-term observations, the $\mathrm{pH}$ value of water in Lake Baikal varies from 7.7 to 8.3 , and during the intense vegetation of picoplanktonic cyanobacteria, it rises to 8.7 (Votintsev, 1961; Khodzher et al., 2018). As shown previously, a key factor in determining the infectivity of a virus is the $\mathrm{pH}$ value. For example, a low $\mathrm{pH}(<4)$ significantly reduces phage survival (Jurczak-Kurek et al., 2016).

In the network analysis, the sequences from Posolsk Sor occupy an intermediate position between planktonic (LT_05 and LT_1015) and coastal sites (Turk) as well as from shallow Mukhor Bay (MK and MC). The distribution pattern can be explained both by the dilution of water in Posolsk Sor with waters of rivers flowing into it and by its closed nature: two sandy spits separate the bay from the lake, and, in contrast to the well-flowing Mukhor Bay, it is connected with the lake only by a narrow $700 \mathrm{~m}$ long channel. With this connection, the sequences from Posolsk Sor are separated from the sequences from the Mukhor Bay, despite the close trophic state of these bays. At the same time, in the UPGMA analysis, they are rather included in the shared cluster with the samples from Mukhor Bay than with the sequences from the pelagic and coastal sites.

Peer) reviewing PDF | (2021:07:63663:2:0:NEW 2 Dec 2021) 
516

517

518

519

520

521

522

523

524

525

526

527

528

529

530

531

532

533

534

535

536

537

538

539

540

541

542

543

544

545

546

547

548

549

550

551

552

553

554

555

Late July and early August is a period of bloom of both pico- and nanoplanktonic cyanobacteria in Lake Baikal. Picocyanobacteria are found in huge numbers in Lake Baikal, reaching an abundance of 1.5 million cells/mL (Belykh \& Sorokovikova, 2003). In August 2019, there was a mass development of diazotrophic cyanobacteria in the waters of the bays: Gloeotrichia echinulata bloomed in Posolsk Sor Bay, and the species of the genus Dolichospermum - in Mukhor Bay. Intensive vegetation of Dolichospermum species has been documented for a long time from June to September in all parts of Lake Baikal, with the maximum concentration of up to 10 million cells/L in bays (Popovskaya, 2000). In this regard, it is logical to assume the presence of cyanophages, natural regulators of the number of cyanobacteria. As mentioned above, many sequences belonged to cyanophages according to RefSeq, but phylogenetic analysis revealed only 12 sequences included in the Exo T-evens group (cyano- and pelagiphages). In addition to cyanophages, Pelagibacter phage HTVC008M (the family Myoviridae) infecting Candidatus Pelagibacter ubique (Alphaproteobacteria, freshwater SAR11) was the closest relative of the Baikal representatives of T4-phages. Previously, high synteny with Candidatus Pelagibacter ubique of the Baikal sequences was determined (CabelloYeves et al., 2018).

To assess the similarity of the Baikal sequences with marine phages, we added the $g 23$ sequences of phages from station ALOHA (Luo et al., 2020), the sequences from viromes obtained from the coastal water of the eutrophic Osaka Bay and viromes (viral and bacterial fraction) of mesotrophic freshwater Lake Biwa. These sequences are absent in the NR and RefSeq databases, which narrows the range of geographic representation of virome communities in aquatic ecosystems. None of these sequences had 100\% identity with OTUs obtained from the bacterial fraction of Lake Baikal, although, in general, the maximum identity was higher with the representatives from the ancient Lake Biwa (up to $89.1 \%$ identity in the bacterial fraction and up to $98 \%$ identity in the viral fraction) than with marine ones from station ALOHA and Osaka Bay (the maximum of $79.8 \%$ identity). This was expected because phages of freshwater ecosystems are more closely related to each other than to marine phages. The sequences from the ancient lakes Biwa and Baikal also did not form separate clusters in the phylogenetic tree but demonstrated high diversity, distributing throughout the tree. The arithmetic means percentage of the sequences from different ecotopes of Lake Baikal ranged from 56 to $66 \%$ with the sequences from viromes. We still cannot reliably answer the question of what ecotope is closer to these of that sequences. Perhaps, this may be due to the method of obtaining the sequences or to low numbers.

Overall, at this stage, it is difficult to identify, with which fraction the studied sequences are more similar: i) the median identity at the amino acid level was slightly higher with the bacterial fraction from Lake Biwa (data not shown); ii) slightly more unique sequences were detected from the bacterial fraction; iii) based on blastp analysis, the highest level of identity was identified with the sequence from the viral fraction. In the future, to elucidate the similarities between the sequences from the ancient lakes, it is necessary to carry out a detailed comparison with other ancient lakes and obtain the $g 23$ sequences by one method.

Peer] reviewing PDF | (2021:07:63663:2:0:NEW 2 Dec 2021) 
556

557

558

559

560

561

562

563

564

565

566

567

568

569

570

571

572

573

574

575

576

577

578

579

580

581

582

583

584

585

586

587

588

589

590

591

592

593

594

595

Noteworthy is a great number of similar sequences in samples from shallow areas of Lake Baikal (from 18.9 to $25.5 \%$ ) and wetland sediments, which is much greater than in the samples from the pelagic zone of Lake Baikal and wetland sediments (from 2.9 to 3.3\%). This possibly indicates the similar composition and conditions for the existence of bacterial communities from the Baikal bays (shallow water, high productivity and elevated temperature) and the shallow well-warmed productive wetland sediments.

A large number of the $g 23$ sequences from lakes Bourget and Annecy similar to the studied Baikal sequences is likely owing to the identity of hydrophysical and hydrochemical parameters (altitude above sea level, total $\mathrm{P}$, total $\mathrm{N}$, nitrates and $\mathrm{pH}$ ) of the lake, as we previously indicated in the analysis of the $g 23$ sequences from the pelagic zone of Lake Baikal (Potapov et al., 2018). Only two sequences had 100\% identity with the Baikal sequences (from Lake Annecy (France) and wetland water (China)), which casts doubt on the "everything is everywhere, but the environment selects" theory, probably, because viruses quickly mutate.

According to (Chow \& Suttle, 2015), four models define biogeography of marine microbiomes and can be applied to viruses: i) local or regional factors do not determine the community composition; ii) the conditions of the local habitat determine the community structure where differences in taxa determine the changes in the community structure (i.e. everything is everywhere but the environment selects for the viability of a community structure); iii) community structure is determined by the extent, to which taxa can migrate to a particular location (i.e., dispersal limitation); iv) dispersal limitation and environmental conditions coregulate community composition. The UPGMA analysis has revealed that viral diversity does not follow the latitudinal and longitudinal gradients, and the geographical distance does not influence the composition of bacteriophages. In our case, the fourth model, "the limitation of distribution and environmental conditions determine the community composition", is the most applicable. Because Lake Baikal was formed separately for many millions of years, determining the composition and the structure of aquatic organisms, this conclusion confirms the separate formation of the viral $g 23$ communities in Lake Baikal and, possibly, endemism of bacteriophages in the Earth's oldest lake. Subcluster Baikal (August), irrespective of the fractions (bacterial or viral), includes the samples taken in August, which coincide with the cyanobacterial bloom period and likely testify to the seasonal division of the clusters. Cluster Baikal (May to June), in addition to neuston, consisted of the samples taken during the spring homothermy when the water column of the lake is actively mixing, and diatoms dominate the plankton (Bondarenko et al., 2019). Neuston is a very specific biotope, and its bacterial and viral composition differs significantly from the water column (Galach'yants et al., 2017; Drucker et al., 2020). Perhaps, for this reason, it was not included in Baikal subcluster. Notably, subcluster consists of the sequences obtained by high throughput sequencing, and Baikal cluster - of the sequences obtained by Sanger sequencing. Possibly, a method of obtaining sequences to some extent affects the results; however, we believe that it does not determine the nature of clustering. The marine sample taken from Kongsfjorden appeared to be in the clade with eutrophic freshwater lakes. Kongsfjorden is exposed to the fresh water influx from several fronts of 
596 glaciers of the Svalbard archipelago (Hagen et al., 2003), causing its desalination and likely

597 bringing bacteria and viruses from the land along with meltwater. Previously, it has been shown

598 that some bacterial sequences from glaciers demonstrate a close identity with those from soils of

599 the temperate zone and humic lakes, i.e. represent cosmopolitan taxa (Edwards et al., 2011). The

600 sample was taken from the glacier's surface $2 \mathrm{~km}$ from the shore, and the mixing of phage

601 communities between glacial and marine habitats was expected, taking into account their close

602 relationship (Bellas \& Anesio, 2013). In general, the main characteristic of the ecosystem

603 (marine, soil or freshwater) substantiates the pattern of distribution of the samples in the

604 UPGMA analysis. We did not include the sequences from viromes in the UPGMA analysis

605 because they were compared to our sequences via blastp analysis and, perhaps, the most distant

606 ones were not detected, i.e. they may not represent the full range of diversity.

607 In the future, to confirm the "uniqueness" of the Baikal $g 23$ sequences, the diversity of T4-

608 bacteriophages in lakes close in age and origin should be compared, for example, Lake Hovsgol

609 (Mongolia) that is close to Lake Baikal, whose age is ca. 5 million years, or geographically very

610 remote Lake Tanganyika (Africa), the age of which is ca. 12 million years (Padilla, 2007;

611 Hampton et al., 2018). Analysis of viral diversity can elucidate the evolution and formation of

612 viral diversity in the lakes that have been isolated for many millions of years.

613

614 Conclusions

615 In this study, we obtained the $g 23$ sequences of planktonic bacteriophages from two

616 shallow bays, as well as coastal and pelagic sites of Lake Baikal, which are part of the bacterial

617 fraction. The $g 23$ sequences were highly diverse and differed from those in other ecosystems.

618 Most sequences from this study had the cultivated closest relatives (RefSeq database) among

619 cyanophages based on blastp analysis. In the network analysis, the sample from Posolsk Sor

620 occupied the intermediate position between the pelagic and coastal samples as well as the sample

621 from Mukhor Bay, again indicating a close relationship between viruses and hosts because

622 different species of cyanobacteria were present in these bays. The sequences from marine

623 viromes differed more than those from the freshwater lake Biwa, which testifies to the close

624 relationship of freshwater viruses and their difference from marine ones. The formation of

625 clusters in the UPGMA analysis allowed us to conclude that the $g 23$ sequences of phages from

626 shallow bays are rather similar to each other than to the sequences from the coastal and pelagic

627 sites of Lake Baikal, i.e. they cluster by the productivity of the sites. In the global UPGMA

628 analysis, all sequences from Lake Baikal formed two clusters depending on the season and were

629 different from the sequences obtained from the seas, soil and sediments, which may indicate the

630 separate formation of viral community in the ancient lake.

631

\section{Acknowledgements}

633 The Authors are grateful to the crew of R/V "G. Titov" for their assistance in sampling. We

634 thank Andrey Fedotov and Yuliya Vitushenko for their helpful advice. The authors are grateful 
635 to Irkutsk Supercomputer Center SB RAS for providing the access to HPC-cluster "Akademik V.

636 M. Matrosov" (MrBayes calculations).

637

638

639

\section{References}

641

642

643

644

645

646

647

648

649

650

651

652

653

654

655

656

657

658

659

660

661

662

663

664

665

666

667

668

669

670

671

672

673

674

675

676

677

678

Ackermann H-W, Krisch HM. 1997. A catalogue of T4-type bacteriophages. Archives of Virology 142:2329-2345. DOI: 10.1007/s007050050246.

Adriaenssens EM, Cowan DA. 2014. Using signature genes as tools to assess environmental viral ecology and diversity. Applied and Environmental Microbiology 80:4470-4480. DOI: 10.1128/AEM.00878-14.

Andrews S. 2010.FastQC: a quality control tool for high throughput sequence data. Available at http://www.bioinformatics.babraham.ac.uk/projects/fastqc/

Auguet JC, Montanié H, Lebaron P. 2006. Structure of virioplankton in the charente estuary (France): Transmission electron microscopy versus pulsed field gel electrophoresis. In: Microbial Ecology. Springer, 197-208. DOI: 10.1007/s00248-005-0043-0.

Aylward FO, Boeuf D, Mende DR, Wood-Charlson EM, Vislova A, Eppley JM, Romano AE, DeLong EF. 2017. Diel cycling and long-term persistence of viruses in the ocean's euphotic zone. Proceedings of the National Academy of Sciences of the United States of America 114:11446-11451. DOI: 10.1073/pnas.1714821114.

Bankevich A, Nurk S, Antipov D, Gurevich AA, Dvorkin M, Kulikov AS, Lesin VM, Nikolenko SI, Pham S, Prjibelski AD, Pyshkin A V., Sirotkin A V., Vyahhi N, Tesler G, Alekseyev MA, Pevzner PA. 2012. SPAdes: A new genome assembly algorithm and its applications to single-cell sequencing. Journal of Computational Biology 19:455-477. DOI: 10.1089/cmb.2012.0021.

Bellas CM, Anesio AM. 2013. High diversity and potential origins of T4-type bacteriophages on the surface of Arctic glaciers. Extremophiles 17:861-870. DOI: 10.1007/s00792-013-0569$\mathrm{x}$.

Belykh OI, Ekaterina G, Sorokovikova T, Saphonova A, Tikhonova I V. 2006. Autotrophic picoplankton of Lake Baikal: Composition, abundance and structure. Hydrobiologia 568:917. DOI: $10.1007 / \mathrm{s} 10750-006-0340-8$.

Belykh OI, Pomazkina G V., Tikhonova I V., Tomberg I V. 2007. Characteristics of Lake Baikal summer phytoplankton and autotrophic picoplankton. International Journal on Algae 9:247-263. DOI: 10.1615/InterJAlgae.v9.i3.50.

Belykh OI, Sorokovikova EG. 2003. Autotrophic picoplankton in Lake Baikal: abundance, dynamics, and distribution. Aquatic Ecosystem Health \& Management 6:251-261. DOI: $10.1080 / 14634980301489$.

Besemer J. 2001. GeneMarkS: a self-training method for prediction of gene starts in microbial genomes. Implications for finding sequence motifs in regulatory regions. Nucleic Acids Research 29:2607-2618. DOI: 10.1093/nar/29.12.2607.

Bolger AM, Lohse M, Usadel B. 2014. Trimmomatic: a flexible trimmer for Illumina sequence data. Bioinformatics (Oxford, England) 30:2114-2120. DOI: 10.1093/bioinformatics/btu170.

Bondarenko NA, Ozersky T, Obolkina LA, Tikhonova IV, Sorokovikova EG, Sakirko MV,

Peer) reviewing PDF | (2021:07:63663:2:0:NEW 2 Dec 2021) 
679

680

681

682

683

684

685

686

687

688

689

690

691

692

693

694

695

696

697

698

699

700

701

702

703

704

705

706

707

708

709

710

711

712

713

714

715

716

717

718

719

720

721

722

723

724

Potapov SA, Blinov VV, Zhdanov AA, Belykh OI. 2019. Recent changes in the spring microplankton of Lake Baikal, Russia. Limnologica 75. DOI: 10.1016/j.limno.2019.01.002.

Buchfink B, Xie C, Huson DH. 2014. Fast and sensitive protein alignment using DIAMOND. Nature Methods 12:59-60. DOI: 10.1038/nmeth.3176.

Buerger P, Weynberg KD, Wood-Charlson EM, Sato Y, Willis BL, van Oppen MJH. 2018. Novel T4 bacteriophages associated with black band disease in corals. Environmental Microbiology. DOI: 10.1111/1462-2920.14432.

Butina TV, Belykh OI, Maksimenko SY, Belikov SI. 2010. Phylogenetic diversity of T4-like bacteriophages in Lake Baikal, East Siberia. FEMS Microbiology Letters 309:122-129. DOI: $10.1111 / \mathrm{j} .1574-6968.2010 .02025 . x$.

Butina TV, Belykh OI, Potapov SA, Sorokovikova EG. 2013. Diversity of the major capsid genes (g23) of T4-like bacteriophages in the eutrophic Lake Kotokel in East Siberia, Russia. Archives of Microbiology 195:513-520. DOI: 10.1007/s00203-013-0884-8.

Cabello-Yeves PJ, Zemskay TI, Rosselli R, Coutinho FH, Zakharenko AS, Blinov V V., Rodriguez-Valera F. 2018. Genomes of novel microbial lineages assembled from the subice waters of Lake Baikal. Applied and Environmental Microbiology 84. DOI: 10.1128/AEM.02132-17.

Cai L, Zhang R, He Y, Feng X, Jiao N. 2016. Metagenomic analysis of Virioplankton of the subtropical Jiulong river estuary, China. Viruses 8:1-13. DOI: 10.3390/v8020035.

Caporaso JG, Kuczynski J, Stombaugh J, Bittinger K, Bushman FD, Costello EK, Fierer N, Peña AG, Goodrich JK, Gordon JI, Huttley G a, Kelley ST, Knights D, Koenig JE, Ley RE, Lozupone C a, Mcdonald D, Muegge BD, Pirrung M, Reeder J, Sevinsky JR, Turnbaugh PJ, Walters W a, Widmann J, Yatsunenko T, Zaneveld J, Knight R. 2010. QIIME allows analysis of high- throughput community sequencing data Intensity normalization improves color calling in SOLiD sequencing. Nature Publishing Group 7:335-336. DOI: 10.1038/nmeth0510-335.

De Cárcer DA, Pedrós-Alió C, Pearce DA, Alcamí A. 2016. Composition and interactions among bacterial, microeukaryotic, and T4-like viral assemblages in lakes from both polar zones. Frontiers in Microbiology 7:1-11. DOI: 10.3389/fmicb.2016.00337.

Chow C-ET, Suttle CA. 2015. Biogeography of viruses in the sea. Annual Review of Virology 2:41-66. DOI: 10.1146/annurev-virology-031413-085540.

Coutinho FH, Cabello-Yeves PJ, Gonzalez-Serrano R, Rosselli R, López-Pérez M, Zemskaya TI, Zakharenko AS, Ivanov VG, Rodriguez-Valera F. 2020. New viral biogeochemical roles revealed through metagenomic analysis of Lake Baikal. Microbiome 8:163. DOI: 10.1186/s40168-020-00936-4.

Danovaro R, Corinaldesi C, Dell'anno A, Fuhrman JA, Middelburg JJ, Noble RT, Suttle CA. 2011. Marine viruses and global climate change. FEMS microbiology reviews 35:993-1034. DOI: 10.1111/J.1574-6976.2010.00258.X.

Desplats C, Krisch HM. 2003. The diversity and evolution of the T4-type bacteriophages. Research in Microbiology 154:259-267. DOI: http://dx.doi.org/10.1016/S09232508(03)00069-X.

Drucker VV, Potapov SA, Gorshkova AS, Belykh OI. 2020. Bacteriophages of Lake Baikal (Bakteriofagi ozera Baykal). Novosibirsk: Russian Academy of Sciences, Siberian Branch. Edgar RC. 2010. Search and clustering orders of magnitude faster than BLAST. Bioinformatics 26:2460-2461. DOI: 10.1093/bioinformatics/btq461.

Edwards A, Anesio AM, Rassner SM, Sattler B, Hubbard B, Perkins WT, Young M, Griffith

Peer] reviewing PDF | (2021:07:63663:2:0:NEW 2 Dec 2021) 
725

726

727

728

729

730

731

732

733

734

735

736

737

738

739

740

741

742

743

744

745

746

747

748

749

750

751

752

753

754

755

756

757

758

759

760

761

762

763

764

765

766

767

768

769

770

GW. 2011. Possible interactions between bacterial diversity, microbial activity and supraglacial hydrology of cryoconite holes in Svalbard. The ISME Journal 5:150-160. DOI: 10.1038/ismej.2010.100.

Filée J, Tétart F, Suttle CA, Krisch HM. 2005. Marine T4-type bacteriophages, a ubiquitous component of the dark matter of the biosphere. Proceedings of the National Academy of Sciences of the United States of America 102:12471-6. DOI: 10.1073/pnas.0503404102. Galach'yants AD, Bel'kova NL, Sukhanova E V, Galach'yants YP, Morozov AA, Parfenova V V. 2017. Taxonomic Composition of Lake Baikal Bacterioneuston Communities. 86:241249. DOI: $10.1134 / \mathrm{S} 0026261717020084$.

Galaziy GI (ed.). 1993. Atlas. Baikal. (In Russian, Russian Academy of Sciences, Siberian branch. Moscow: Federal Service of geodesy and cartography.

Garin-Fernandez A, Pereira-flores E, Oliver F, Wichels A. 2018. Marine Genomics The North Sea goes viral : Occurrence and distribution of North Sea bacteriophages. Marine Genomics 41:31-41. DOI: 10.1016/j.margen.2018.05.004.

Goldsmith DB, Parsons RJ, Beyene D, Salamon P, Breitbart M. 2015. Deep sequencing of the viral phoH gene reveals temporal variation, depth-specific composition, and persistent dominance of the same viral phoH genes in the Sargasso Sea. PeerJ 3:e997. DOI: 10.7717/peerj.997.

Gong Z, Liang Y, Wang M, Jiang Y, Yang Q, Xia J, Mcminn A. 2018. Viral diversity and its relationship with environmental factors at the surface and deep sea of Prydz Bay , Antarctica. 9:1-17. DOI: 10.3389/fmicb.2018.02981.

Gregory AC, Zayed AA, Conceição-Neto N, Temperton B, Bolduc B, Alberti A, Ardyna M, Arkhipova K, Carmichael M, Cruaud C, Dimier C, Domínguez-Huerta G, Ferland J, Kandels S, Liu Y, Marec C, Pesant S, Picheral M, Pisarev S, Poulain J, Tremblay JÉ, Vik D, Acinas SG, Babin M, Bork P, Boss E, Bowler C, Cochrane G, de Vargas C, Follows M, Gorsky G, Grimsley N, Guidi L, Hingamp P, Iudicone D, Jaillon O, Kandels-Lewis S, Karp-Boss L, Karsenti E, Not F, Ogata H, Poulton N, Raes J, Sardet C, Speich S, Stemmann L, Sullivan MB, Sunagawa S, Wincker P, Culley AI, Dutilh BE, Roux S. 2019. Marine DNA viral macro- and microdiversity from pole to pole. Cell 177:1109-1123.e14. DOI: 10.1016/j.cell.2019.03.040.

Hagen JO, Kohler J, Melvold K, Winther J-G. 2003. Glaciers in Svalbard: mass balance, runoff and freshwater flux. Polar Research 22:145-159. DOI: 10.3402/polar.v22i2.6452.

Hall T. 1999. BioEdit: a user-friendly biological sequence alignment editor and analysis program for Windows 95/98/NT. Nucleic Acids Symposium Series 41:95-98. DOI: citeulike-articleid:691774.

Hampton SE, McGowan S, Ozersky T, Virdis SGP, Vu TT, Spanbauer TL, Kraemer BM, Swann G, Mackay AW, Powers SM, Meyer MF, Labou SG, O’Reilly CM, DiCarlo M, Galloway AWE, Fritz SC. 2018. Recent ecological change in ancient lakes. Limnology and Oceanography 63:2277-2304. DOI: 10.1002/LNO.10938.

He M, Cai L, Zhang C, Jiao N, Zhang R. 2017. Phylogenetic diversity of T4-type phages in sediments from the subtropical Pearl River Estuary. Frontiers in Microbiology 8. DOI: 10.3389/fmicb.2017.00897.

Hohmann R, Kipfer R, Peeters F, Piepke G, Imboden DM, Shimaraev MN. 1997. Processes of deep-water renewal in Lake Baikal. Limnology and Oceanography 42:841-855. DOI: 10.4319/LO.1997.42.5.0841.

Huang H-Z, Cheng K, Xu M. 2011. Genetic diversity of T4 virioplankton, inferred from g23

Peer) reviewing PDF | (2021:07:63663:2:0:NEW 2 Dec 2021) 
771

772

773

774

775

776

777

778

779

780

781

782

783

784

785

786

787

788

789

790

791

792

793

794

795

796

797

798

799

800

801

802

803

804

805

806

807

808

809

810

811

812

813

814

815

816

gene, in Wuhan Donghu Lake. China environmental science 31:443-447.

Huelsenbeck JP, Ronquist F. 2001. MRBAYES: Bayesian inference of phylogenetic trees. Bioinformatics 17:754-755.

ICTV. 2019.Master Species List 2019.v1. Available at https://talk.ictvonline.org/files/masterspecies-lists $/ \mathrm{m} / \mathrm{msl} / 9601$

Jamindar S, Polson SW, Srinivasiah S, Waidner L, Wommack KE. 2012. Evaluation of two approaches for assessing the genetic similarity of virioplankton populations as defined by genome size. Applied and Environmental Microbiology 78:8773-8783. DOI: 10.1128/AEM.02432-12.

Jurczak-Kurek A, Gąsior T, Nejman-Faleńczyk B, Bloch S, Dydecka A, Topka G, Necel A, Jakubowska-Deredas M, Narajczyk M, Richert M, Mieszkowska A, Wróbel B, Węgrzyn G, Węgrzyn A. 2016. Biodiversity of bacteriophages: morphological and biological properties of a large group of phages isolated from urban sewage. Scientific Reports 6:34338. DOI: $10.1038 /$ srep34338.

Khodzher TV, Domysheva VM, Sorokovikova LM, Tomberg IV, Sakirko MV. 2018. Hydrochemical studies in Lake Baikal: history and nowadays. Limnology and Freshwater Biology:2-9. DOI: 10.31951/2658-3518-2018-A-1-2.

Knapik K, Prentice MB. 2012.Wide bacteriophage diversity in a single terrestrial aquatic site. Available at https://www.ncbi.nlm.nih.gov/popset? LinkName=protein_popset\&from_uid=396575579

Komárek J. 2013. Cyanoprokaryota - 3. Teil / 3rd part: Heterocytous Genera. In: Büdel B, Gärtner G, Krienitz L eds. Süßwasserflora von Mitteleuropa, Bd. 19/3. 1131.

Komárek J, Anagnostidis K. 2008. Cyanoprokaryota. 1. Teil, Chroococcales. Springer Spektrum.

Kozhova OM, Izmest'eva LR. 1998. Lake Baikal: Evolutionand Biodiversity.

Krishnamurthy SR, Wang D. 2017. Origins and challenges of viral dark matter. Virus Research 239:136-142. DOI: 10.1016/j.virusres.2017.02.002.

Kumar S, Stecher G, Tamura K. 2016. MEGA7: molecular evolutionary genetics analysis version 7.0 for bigger datasets. Molecular biology and evolution 33:msw054. DOI: 10.1093/molbev/msw054.

Kutter E, Sulakvelidze A. 2005. Bacteriophages: Biology and Applications. Boca RatonLondon- New York- Washington: CRC Press.

Li W, Godzik A. 2006. Cd-hit: A fast program for clustering and comparing large sets of protein or nucleotide sequences. Bioinformatics 22:1658-1659. DOI: 10.1093/bioinformatics/btl158.

Li Y, Liu H, Pan H, Zhu X, Liu C, Zhang Q, Luo Y, Di H, Xu J. 2019. T4-type viruses: Important impacts on shaping bacterial community along a chronosequence of 2000-year old paddy soils. Soil Biology and Biochemistry 128:89-99. DOI: 10.1016/j.soilbio.2018.10.007.

Li X, Sun Y, Liu J, Yao Q, Wang G. 2018. Myoviridae environmental samples. Available at https://www.ncbi.nlm.nih.gov/popset?LinkName=protein_popset\&from_uid=1496533459

Likens GE. 1975. Primary production of inland aquatic ecosystems. In: Leith H, Whittaker RR eds. Primary production of the biosphere. New York: Springer-Verlag, 185-202.

Liu L, Cai L, Zhang R. 2017. Co-existence of freshwater and marine T4-like myoviruses in a typical subtropical estuary. FEMS Microbiology Ecology 93. DOI: 10.1093/femsec/fix 119. López-Bueno A, Tamames J, Velázquez D, Moya A, Quesada A, Alcamí A. 2009. High 
817

818

819

820

821

822

823

824

825

826

827

828

829

830

831

832

833

834

835

836

837

838

839

840

841

842

843

844

845

846

847

848

849

850

851

852

853

854

855

856

857

858

859

860

861

862

diversity of the viral community from an Antarctic lake. Science 326:858-861. DOI: 10.1126/science. 1179287.

Luo E, Eppley JM, Romano AE, Mende DR, DeLong EF. 2020. Double-stranded DNA virioplankton dynamics and reproductive strategies in the oligotrophic open ocean water column. The ISME Journal 2020 14:5 14:1304-1315. DOI: 10.1038/s41396-020-0604-8.

Millard AD, Pearce D, Zwirglmaier K. 2016. Biogeography of bacteriophages at four hydrothermal vent sites in the Antarctic based on g23 sequence diversity. FEMS Microbiology Letters 363:1-12. DOI: 10.1093/femsle/fnw043.

Mruwat N, Carlson MCG, Goldin S, Ribalet F, Kirzner S, Hulata Y, Beckett SJ, Shitrit D, Weitz JS, Armbrust EV, Lindell D. 2021. A single-cell polony method reveals low levels of infected Prochlorococcus in oligotrophic waters despite high cyanophage abundances. The ISME Journal 15:41-54. DOI: 10.1038/s41396-020-00752-6.

Murtagh F. 1992. Comments on "Parallel algorithms for hierarchical clustering and cluster validity." IEEE Transactions on Pattern Analysis and Machine Intelligence 14:1056-1057. DOI: $10.1109 / 34.159908$.

Nishimura Y, Watai H, Honda T, Mihara T, Omae K, Roux S, Blanc-Mathieu R, Yamamoto K, Hingamp P, Sako Y, Sullivan MB, Goto S, Ogata H, Yoshida T. 2017. Environmental Viral Genomes Shed New Light on Virus-Host Interactions in the Ocean. mSphere 2. DOI: 10.1128/MSPHERE.00359-16.

Okazaki Y, Nishimura Y, Yoshida T, Ogata H, Nakano S. 2019. Genome - resolved viral and cellular metagenomes revealed potential key virus - host interactions in a deep freshwater lake. Environmental Microbiology 21:4740-4754. DOI: 10.1111/1462-2920.14816.

Padilla DK. 2007. The Geology, Biodiversity and Ecology of Lake Hövsgöl (Mongolia). Biology of Inland Waters. Edited by Clyde E Goulden, Tatiana Sitnikova, Jon Gelhaus, and, Bazartseren Boldgiv. Leiden (The Netherlands): Backhuys Publishers . €176.00. xxi +525 p; ill.; s. The Quarterly Review of Biology 82:69-70. DOI: 10.1086/513386.

De Paepe M, Taddei F. 2006. Viruses' life history: towards a mechanistic basis of a trade-off between survival and reproduction among phages. PLoS Biology 4:e193. DOI: 10.1371/journal.pbio.0040193.

Palermo CN, Fulthorpe RR, Saati R, Short SM. 2019. Metagenomic analysis of virus diversity and relative abundance in a eutrophic freshwater Harbour. Viruses 11:792. DOI: 10.3390/v11090792.

Parvathi A, Zhong X, Jacquet S. 2012. Dynamics of various viral groups infecting autotrophic plankton in Lake Geneva. Advances in Oceanography and Limnology 3:171-191. DOI: 10.1080/19475721.2012.738157.

Paul JH, Jiang SC, Rose JB. 1991. Concentration of viruses and dissolved DNA from aquatic environments by vortex flow filtration. Applied and Environmental Microbiology 57:21972204. DOI: 10.1128/aem.57.8.2197-2204.1991.

Popovskaya G. 2000. Ecological monitoring of phytoplankton in Lake Baikal. Aquatic Ecosystem Health and Management 3:215-225. DOI: 10.1016/S1463-4988(00)00021-X.

Potapov S, Belykh O, Krasnopeev A, Galachyants A, Podlesnaya G, Khanaev I, Tikhonova I. 2020. Diversity and biogeography of bacteriophages in biofilms of Lake Baikal based on g23 sequences. Journal of Great Lakes Research 46. DOI: 10.1016/j.jglr.2019.06.007.

Potapov S, Belykh O, Krasnopeev A, Gladkikh A, Kabilov M, Tupikin A, Butina T. 2018. Assessing the diversity of the g23 gene of T4-like bacteriophages from Lake Baikal with high-throughput sequencing. FEMS microbiology letters 365. DOI: 10.1093/femsle/fnx264.

Peer] reviewing PDF | (2021:07:63663:2:0:NEW 2 Dec 2021) 
863 Potapov SA, Butina T V., Belykh OI, Belikov SI. 2013. Genetic diversity of T4-like

864 bacteriophages in Lake Baikal. «The Bulletin of Irkutsk State University». Series «Biology.

865 Ecology». 3:14-19.

866

867

868

869

870

871

872

873

874

875

876

877

878

879

880

881

882

883

884

885

886

887

888

889

890

891

892

893

894

895

896

897

898

899

900

901

902

903

904

905

906

907

908

Rozas J, Ferrer-Mata A, Sánchez-DelBarrio JC, Guirao-Rico S, Librado P, Ramos-Onsins SE, Sánchez-Gracia A. 2017. DnaSP 6: DNA sequence polymorphism analysis of large data sets. Molecular Biology and Evolution 34:3299-3302. DOI: 10.1093/molbev/msx248.

Shannon P. 2003. Cytoscape: A Software Environment for Integrated Models of Biomolecular Interaction Networks. Genome Research 13:2498-2504. DOI: 10.1101/gr.1239303.

Sime-Ngando T, Boivin P, Chapron E, Jézéquel D, Meybeck M. 2016. Lake Pavin: History, geology, biogeochemistry, and sedimentology of a deep meromictic maar lake. Lake Pavin: History, Geology, Biogeochemistry, and Sedimentology of a Deep Meromictic Maar Lake:1-421. DOI: 10.1007/978-3-319-39961-4.

Sneath PHA, Sokal RR. 1973. Numerical Taxonomy: The Principles and Pratice of Numerical Classification. San Francisco: Freeman.

Straškrábová V, Izmest'yeva LRR, Maksimova EAA, Fietz S, Nedoma J, Borovec J, Kobanova GII, Shchetinina EV V., Pislegina EV V., Stra??kr??bov?? V, Izmest'yeva LRR, Maksimova EAA, Fietz S, Nedoma J, Borovec J, Kobanova GII, Shchetinina EV V., Pislegina EV V. 2005. Primary production and microbial activity in the euphotic zone of Lake Baikal (Southern Basin) during late winter. Global and Planetary Change 46:57-73. DOI: 10.1016/j.gloplacha.2004.11.006.

Sullivan MB, Waterbury JB, Chisholm SW. 2003. Cyanophages infecting the oceanic cyanobacterium Prochlorococcus. Nature 424:1047-1051. DOI: 10.1038/nature01929.

Suttle CA. 2007. Marine viruses - major players in the global ecosystem. 5:801-812. DOI: $10.1038 /$ nrmicro1750.

Taboada B, Isa P, Gutiérrez-Escolano AL, del Ángel RM, Ludert JE, Vázquez N, Tapia-Palacios MA, Chávez P, Garrido E, Espinosa AC, Eguiarte LE, López S, Souza V, Arias CF. 2018. The Geographic Structure of Viruses in the Cuatro Ciénegas Basin, a Unique Oasis in Northern Mexico, Reveals a Highly Diverse Population on a Small Geographic Scale. Applied and Environmental Microbiology 84. DOI: 10.1128/AEM.00465-18.

Tetart F, Desplats C, Kutateladze M, Monod C, Desplats C, Kutateladze M, Monod C, Ackermann H-WW, Krisch HM. 2001. Phylogeny of the major head and tail genes of the wide-ranging T4-type bacteriophages. Journal of bacteriology 183:358-366. DOI: 10.1128/JB.183.1.358-366.2001.

Votintsev K. 1961. Water chemistry of Lake Baikal. Trudy Baikalskoi limnologicheskoi stantsii AN SSSR [Proceedings of the Baikal Limnological Station of the Academy of Sciences of the USSR] (In Russia) 20:1-311.

Wang MN, Ge XY, Wu YQ, Yang X Lou, Tan B, Zhang YJ, Shi ZL. 2015. Genetic diversity and temporal dynamics of phytoplankton viruses in East Lake, China. Virologica Sinica 30:290-300. DOI: 10.1007/s12250-015-3603-6.

Wang G, Hayashi M, Saito M, Tsuchiya K, Asakawa S, Kimura M. 2009. Survey of major capsid genes (g23) of T4-type bacteriophages in Japanese paddy field soils. Soil Biology and Biochemistry 41:13-20. DOI: 10.1016/j.soilbio.2008.07.008.

Warwick-Dugdale J, Buchholz HH, Allen MJ, Temperton B. 2019. Host-hijacking and planktonic piracy: how phages command the microbial high seas. Virology Journal 16:15. DOI: $10.1186 / \mathrm{s} 12985-019-1120-1$.

Watanabe Y, Drucker VV. 1999. Phytoplankton blooms in Lake Baikal, with reference to the

Peer] reviewing PDF | (2021:07:63663:2:0:NEW 2 Dec 2021) 
909

910

911

912

913

914

915

916

917

918

919

920

921

922

923

924

925

926

927

928

929

930

931

932

933

lake's present state of eutrophication. In: Kawanabe H, Coulter GG, Roosevelt AC eds. Ancient Lakes: Their Cultural and Biological Diversity. Kenobi Productions: Belgium, 217-225.

Wetzel RG, Likens GE. 2000. Limnological Analyses. New York, NY: Springer New York. DOI: $10.1007 / 978-1-4757-3250-4$.

Wu S, Zhou L, Zhou Y, Wang H, Xiao J, Yan S, Wang Y. 2020. Diverse and unique viruses discovered in the surface water of the East China Sea. BMC Genomics 21:441. DOI: 10.1186/s12864-020-06861-y.

Zeigler Allen L, McCrow JP, Ininbergs K, Dupont CL, Badger JH, Hoffman JM, Ekman M, Allen AE, Bergman B, Venter JC. 2017. The Baltic Sea virome: diversity and transcriptional activity of DNA and RNA viruses. mSystems 2:e0125-16. DOI: 10.1128/mSystems.00125-16.

Zhang QY, Gui JF. 2018. Diversity, evolutionary contribution and ecological roles of aquatic viruses. Science China Life Sciences 61:1486-1502. DOI: 10.1007/s11427-018-9414-7.

Zhao Y, Temperton B, Thrash JC, Schwalbach MS, Vergin KL, Landry ZC, Ellisman M, Deerinck T, Sullivan MB, Giovannoni SJ. 2013. Abundant SAR11 viruses in the ocean. Nature 494:357-360. DOI: 10.1038/nature11921.

Zheng C, Wang G, Liu J, Song C, Gao H, Liu X. 2013. Characterization of the major capsid genes (g23) of T4-type bacteriophages in the wetlands of Northeast China. Microbial Ecology 65:616-625. DOI: 10.1007/s00248-012-0158-z.

Zhong X, Jacquet S. 2014. Differing assemblage composition and dynamics in T4-like myophages of two neighbouring sub-alpine lakes. Freshwater Biology 59:1577-1595. DOI: $10.1111 /$ fwb. 12365 . 


\section{Figure 1}

Map of the sampling area. Imagery @2021 NASA, TerraMetrics, Map data @2021 INEGI

MK - Mukhor Bay near the Kuchelga River, MC - center of Mukhor Bay, Turk - coastal zone near the Turka, Posol_S - Posolsk Sor Bay, LT_05 - central station of the Listvyanka settlement - the Tankhoy settlement section, sampling was carried out in the layer from $0+$ 5 m, LT_1015 - central station of the Listvyanka settlement - the Tankhoy settlement section; sampling was carried out in the layer from $10+15 \mathrm{~m}$. 


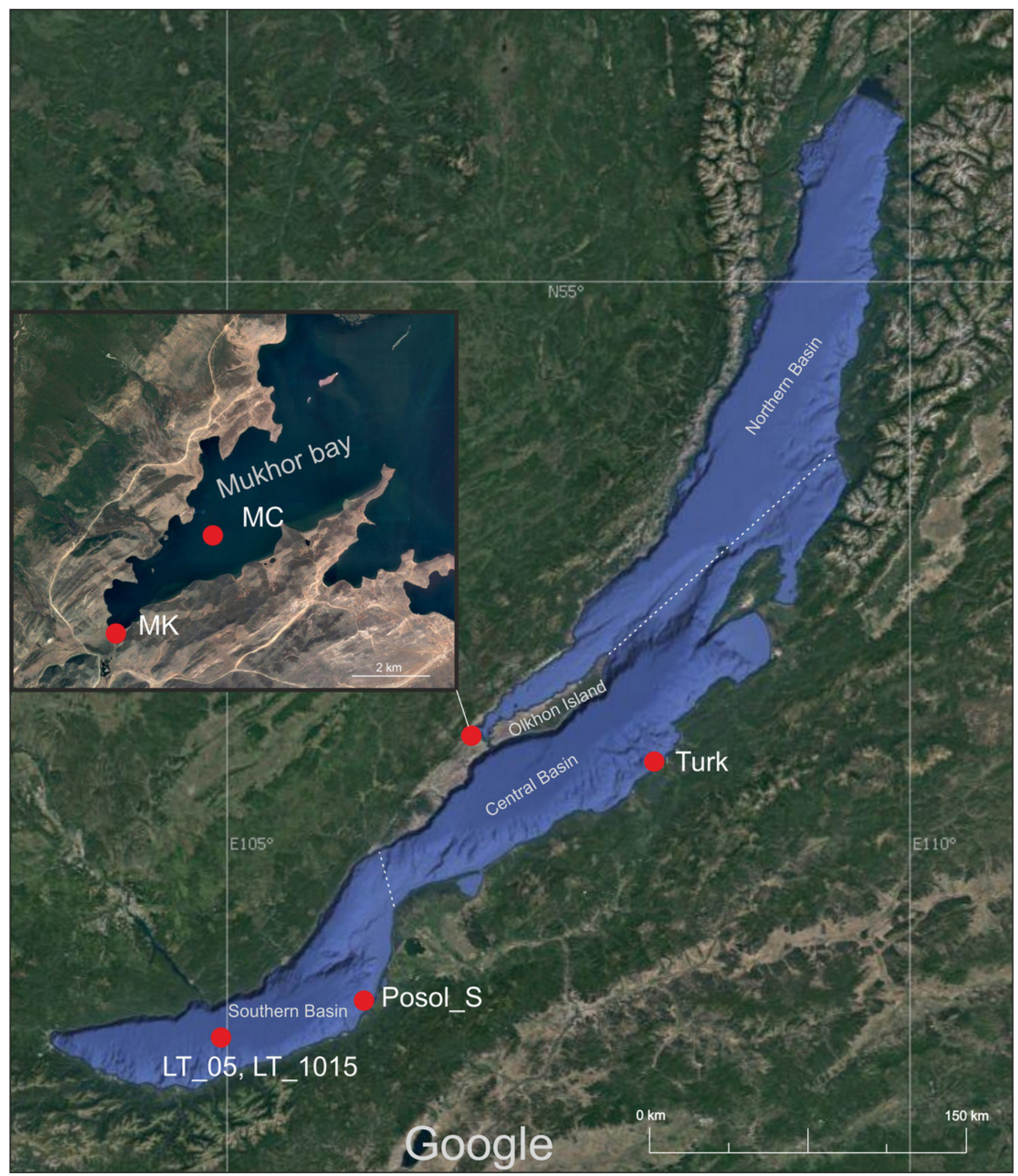




\section{Figure 2}

Bayesian phylogenetic tree based on the alignment of $438 \mathrm{~g} 23$ major capsid protein sequences.

LAB - Lake Bourget and Annecy, WS - wetland sediments, EL - East Lake, sPRE - sediments of Perl River estuary, BW - Borehole water, DL - Donghu Lake, WW- wetland water, DW - dairy wastewater, PW - paddy water, RF - rice field, SRF - the soil of rice field, LL - Lake Limnopolar, KL - Lake Kotokel, LS, 2D1, 2D2, 2D4, 2a - biofilms (Lake Baikal), NB - Neuston Lake Baikal, OBV - Osaka Bay, HOT - sampling site of the Hawaii Ocean Time-series program, BacFR Lake Biwa (bacterial fraction), VirFR - Lake Biwa (viral fraction). Gray circles represent 19 clusters. 


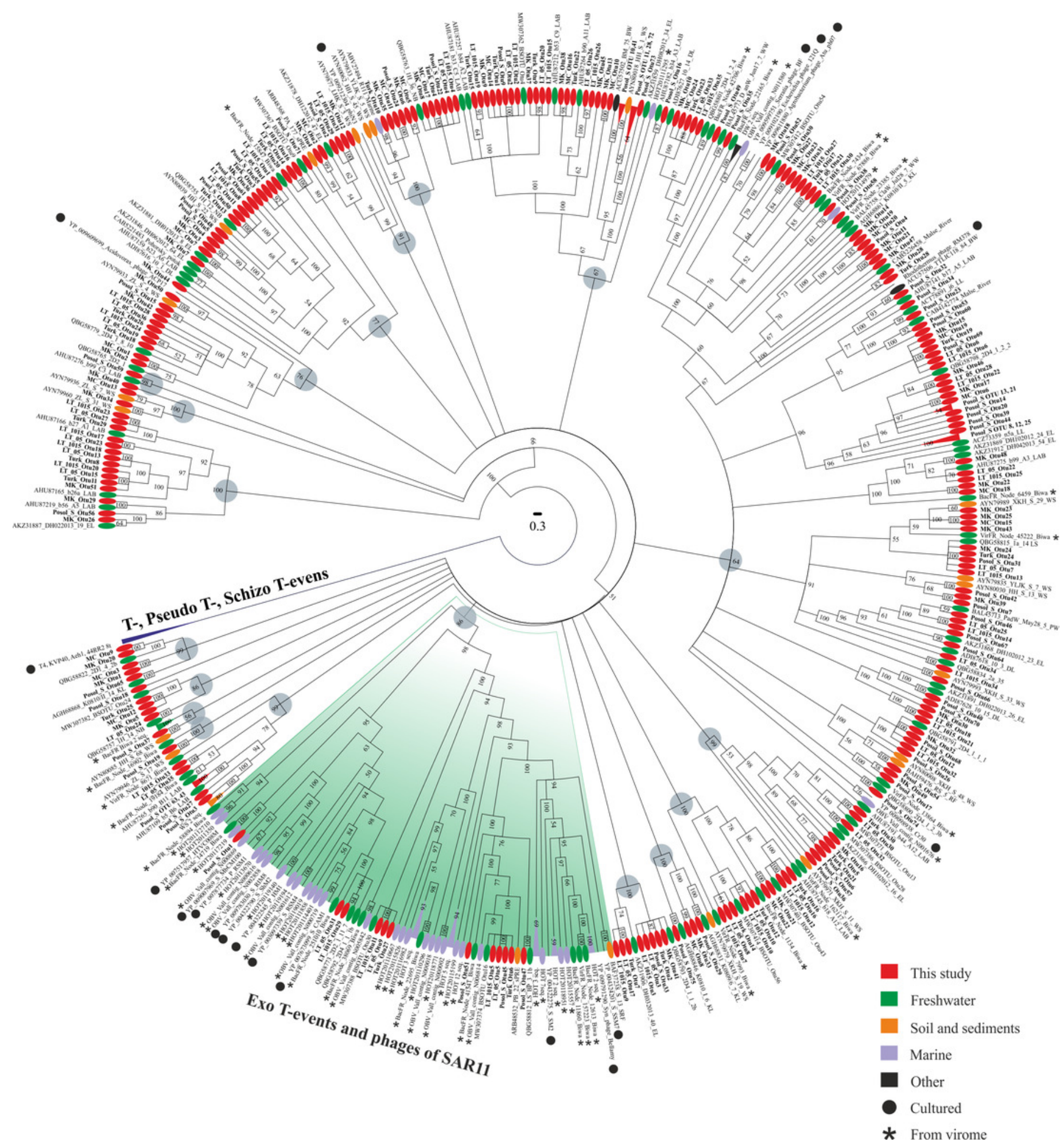




\section{Figure 3}

Network demonstrating the relationship of the studied OTUs with other previously obtained sequences: S0508 and N0508 (Butina et al., 2010); 2D1, 1D3Tp, 2D2, 2D4, and Neuston (Potapov et al., 2020) ; Lake Kotokel (Butina et al., 2013).

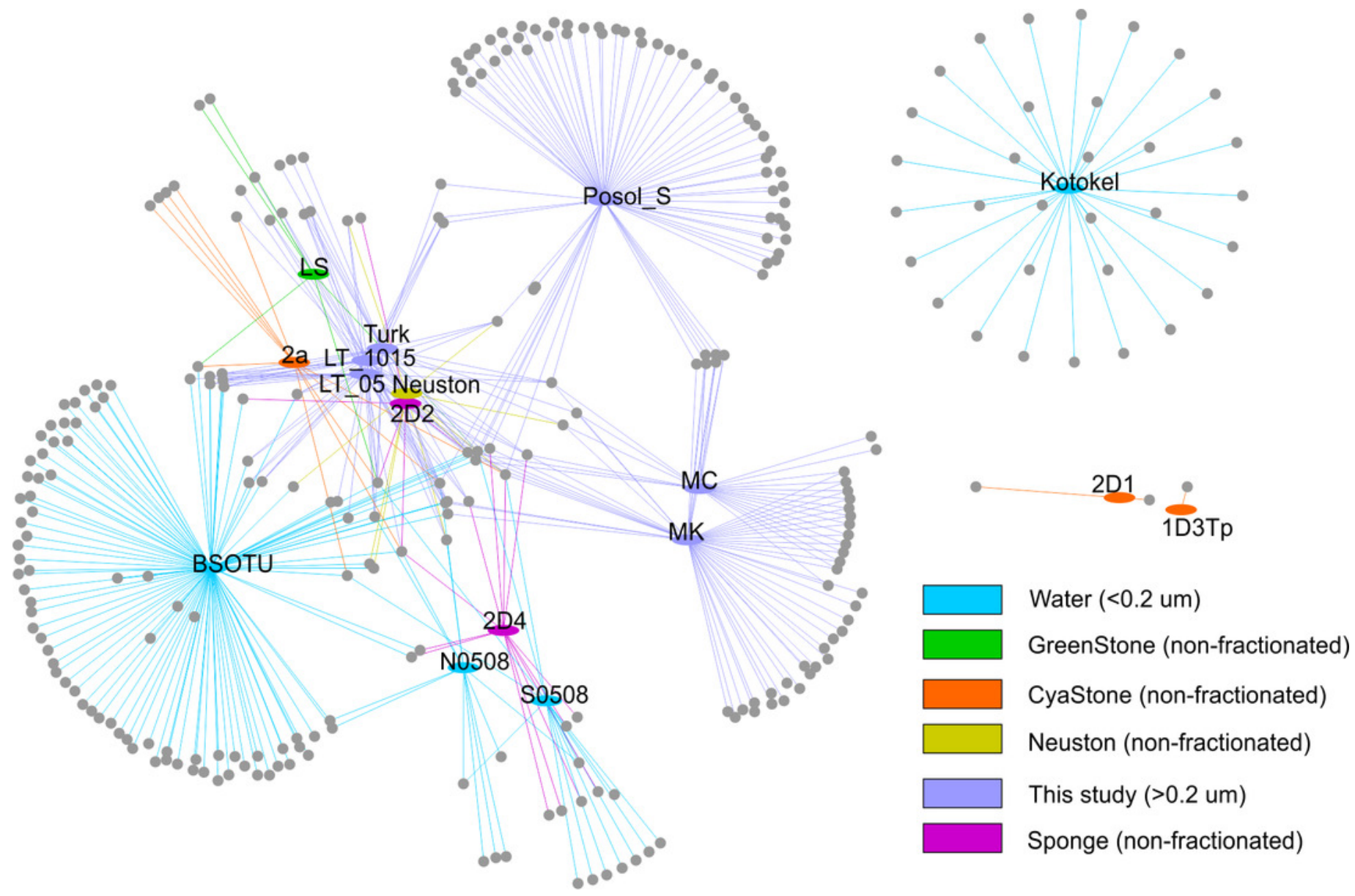


Figure 4

Map showing the samples included in the analysis for this study. Map data @2021 Google, INEGI.

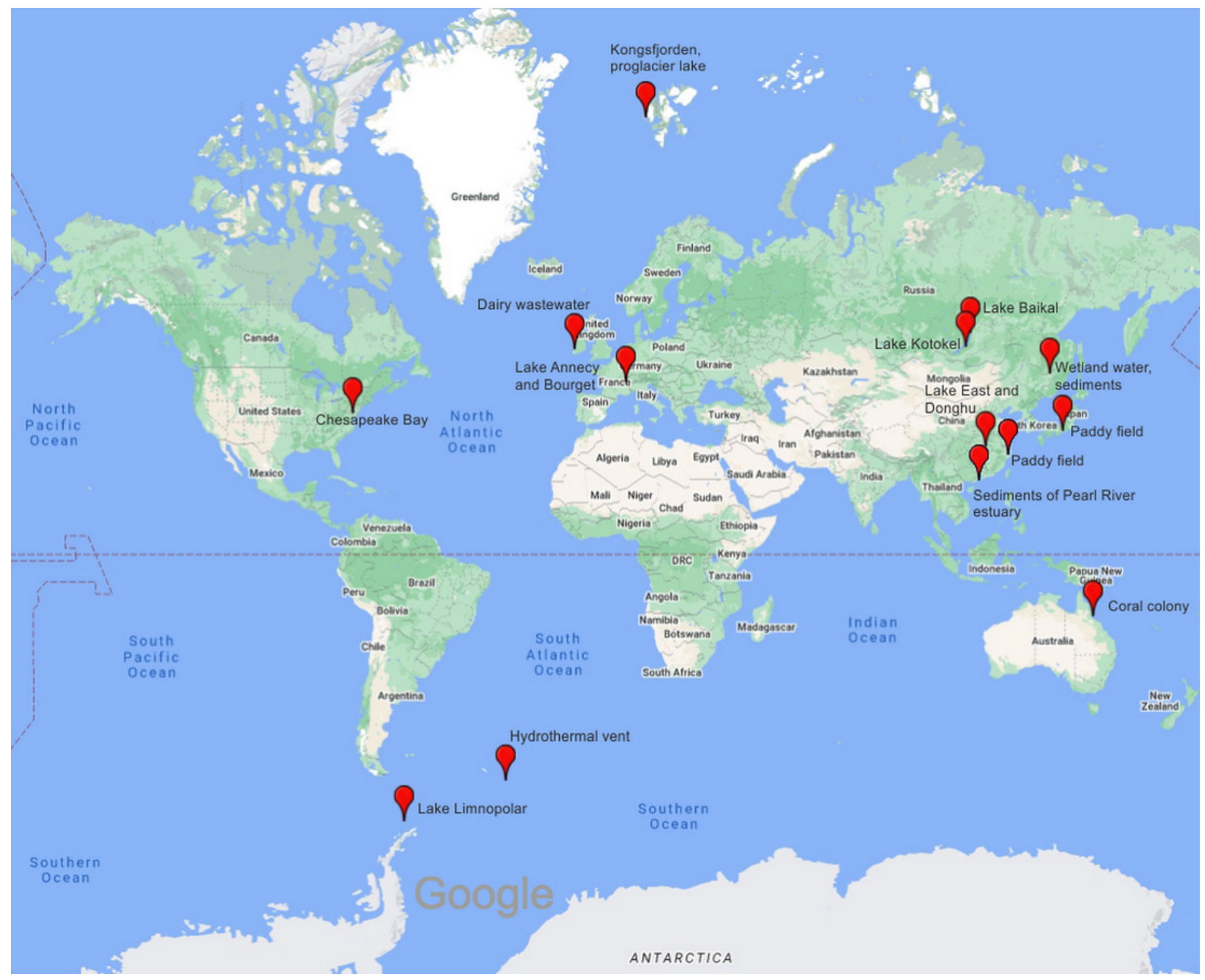


Figure 5

Cluster dendrogram (UPGMA). Samples from this study are marked in bold.

S0508 - southern basin, Lake Baikal, N0508 - northern basin, Lake Baikal, BSOTU - Baikal OTU samples, LAB - lakes Bourget and Annecy. Untagged samples are either unpublished or have no open access articles. 


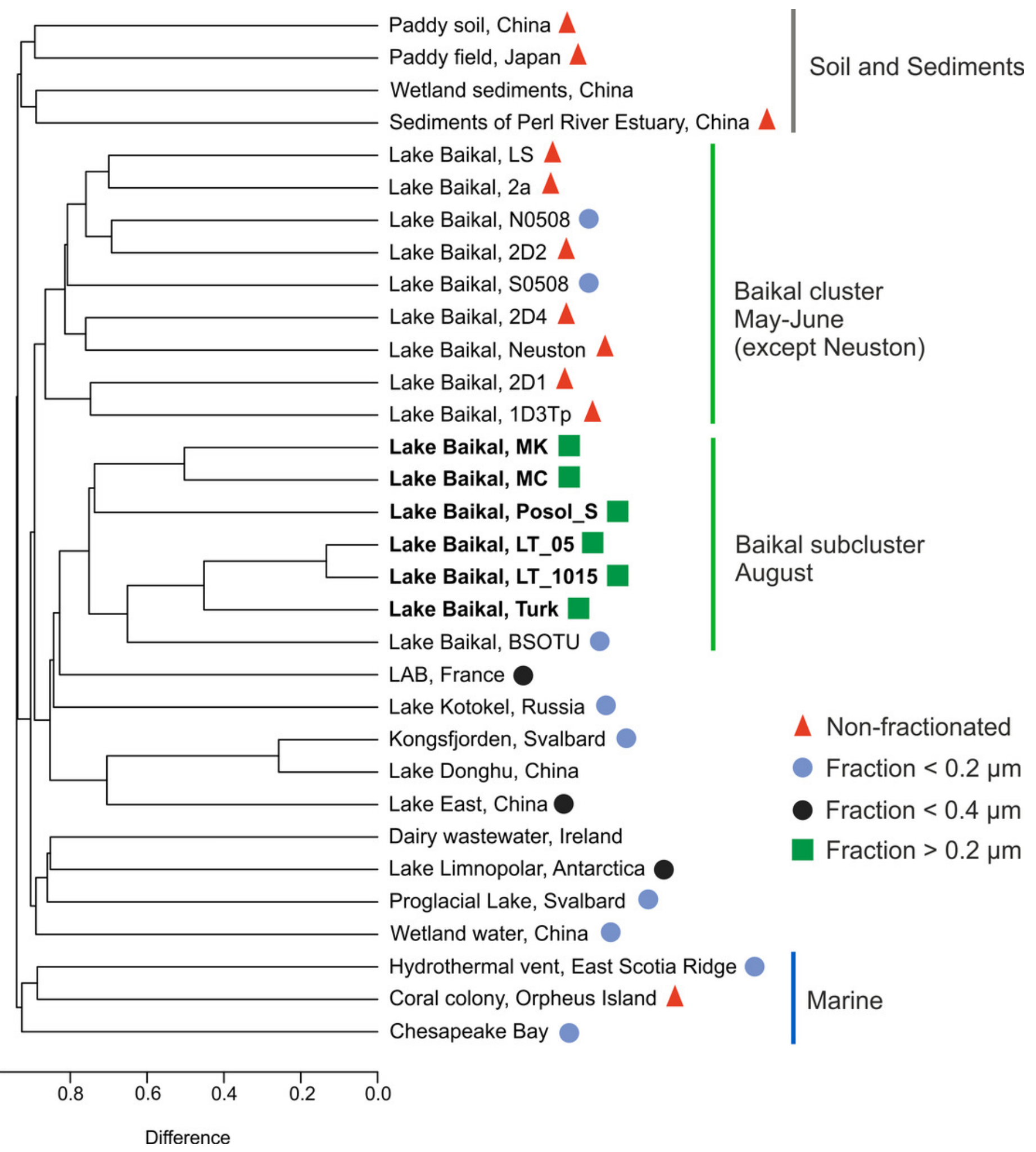




\section{Table 1 (on next page)}

Physical and chemical parameters of water 
1

\begin{tabular}{|l|c|l|l|l|l|c|}
\hline & $\begin{array}{l}\text { MK } \\
\text { shallow } \\
\text { bay }\end{array}$ & $\begin{array}{l}\text { MC } \\
\text { shallow } \\
\text { bay }\end{array}$ & $\begin{array}{l}\text { Turk } \\
\text { coastal } \\
\text { zone }\end{array}$ & $\begin{array}{l}\text { Posol_S } \\
\text { shallow } \\
\text { bay }\end{array}$ & $\begin{array}{l}\text { LT_05 } \\
\text { pelagic } \\
\text { zone }\end{array}$ & $\begin{array}{l}\text { LT_1015 } \\
\text { pelagic } \\
\text { zone }\end{array}$ \\
\hline Sampling horizon, $\mathrm{m}$ & 0 & 0 & 0 & 0 & $0-5$ & $10-15$ \\
\hline Water temperature, ${ }^{\circ} \mathrm{C}$ & 19.6 & 21.5 & 17.3 & 19 & $\begin{array}{c}12 \\
\text { (average) }\end{array}$ & $\begin{array}{c}6.2 \\
\text { (average) }\end{array}$ \\
\hline $\mathrm{pH}$ & 8.2 & 8.6 & 8.3 & 8.2 & 8.2 & 8.2 \\
\hline $\mathrm{P}_{\text {total }}, \mu \mathrm{g} / 1$ & 12.8 & 13.5 & 10 & 12 & 7.8 & 8.2 \\
\hline $\mathrm{N}_{\text {total }}, \mathrm{mg} / 1$ & 0.23 & 0.26 & 1.3 & 2 & 0.11 & 0.13 \\
\hline $\mathrm{Chl} a, \mu / 1$ & 4.8 & 4.8 & 1.1 & 25 & 1.8 & 2.1 \\
\hline
\end{tabular}

2 


\section{Table 2 (on next page)}

Nucleotide diversity of the $g 23$ gene fragment. Samples from Lake Baikal are marked in bold; samples obtained in this study are highlighted in grey. 
Table 2

\begin{tabular}{|c|c|c|}
\hline Sample & Nucleotide diversity, $\pi$ & References \\
\hline Lake Baikal, LS & 0.38 & (Potapov et al., 2020) \\
\hline Lake Limnopolar (Antarctica) & 0.37 & $\begin{array}{c}\text { (López-Bueno et al., } \\
\text { 2009) }\end{array}$ \\
\hline Dairy water (Ireland) & 0.37 & $\begin{array}{c}\text { (Knapik \& Prentice, } \\
\text { 2012) }\end{array}$ \\
\hline Lake Baikal, 2D4 & 0.37 & (Potapov et al., 2020) \\
\hline MK & 0.36 & This study \\
\hline MC & 0.35 & This study \\
\hline Turk & 0.35 & This study \\
\hline Paddy field (China) & 0.35 & (Li et al., 2019) \\
\hline Lake Baikal, 2a & 0.35 & (Potapov et al., 2020) \\
\hline LT_1015 & 0.34 & This study \\
\hline Lake Proglacial (Svalbard) & 0.34 & (Bellas \& Anesio, 2013) \\
\hline Lake Kotokel (Russia) & 0.34 & (Butina et al., 2013) \\
\hline LT_05 & 0.33 & This study \\
\hline Kongsfjorden (Svalbard) & 0.33 & (Bellas \& Anesio, 2013) \\
\hline Lake Baikal (South basin) & $\mathbf{0 . 3 3}$ & (Butina et al., 2010) \\
\hline Paddy field (Japan) & 0.33 & (Cahyani et al., 2009) \\
\hline Wetland, water (China) & 0.32 & (Zheng et al., 2013) \\
\hline Posol_S & 0.31 & This study \\
\hline Lake Donghu (China) & 0.31 & $\begin{array}{l}\text { (Huang, Cheng \& Xu, } \\
\text { 2011) }\end{array}$ \\
\hline Lake Baikal, 2D2 & 0.30 & (Potapov et al., 2020) \\
\hline Hydrothermal vent (East Scotia Ridge) & 0.30 & $\begin{array}{l}\text { (Millard, Pearce \& } \\
\text { Zwirglmaier, 2016) }\end{array}$ \\
\hline Lake Baikal (North basin) & 0.30 & (Butina et al., 2010) \\
\hline Chesapeake Bay & 0.29 & (Jamindar et al., 2012) \\
\hline Lake East (China) & 0.29 & (Wang et al., 2015) \\
\hline Wetland sediments (China) & 0.29 & (Li et al., 2018) \\
\hline Lake Baikal, pelagic water (South basin) & 0.28 & (Potapov et al., 2018) \\
\hline Lake Annecy and Bourget (France) & 0.28 & (Zhong \& Jacquet, 2014) \\
\hline Sediments of Pearl River Estuary (China) & 0.28 & (He et al., 2017) \\
\hline Lake Baikal, Neuston & 0.27 & (Potapov et al., 2020) \\
\hline Coral colony (Orpheus Island) & 0.23 & (Buerger et al., 2018) \\
\hline Lake Baikal, 2D1 & 0.14 & (Potapov et al., 2020) \\
\hline Lake Baikal, 1D3Tp & $\mathbf{0 . 0 3}$ & (Potapov et al., 2020) \\
\hline
\end{tabular}




\section{Table 3 (on next page)}

The number of sequences in this study similar to the sequences from other sources (uncultivated), \% (database GenBank NR, amino acid level). 


\begin{tabular}{|c|c|c|c|c|c|c|c|}
\hline Isolation source & MK & $\mathrm{MC}$ & Turk & Posol_S & LT 05 & LT 1015 & Reference \\
\hline Biofilms, Lake Baikal (Russia) & 19.6 & 20.8 & 20 & 27 & 27.8 & 28.6 & $\begin{array}{c}\text { (Potapov et } \\
\text { al., 2020) }\end{array}$ \\
\hline Pelagic water, Lake Baikal (Russia) & 9.8 & 12.5 & 30 & 6.8 & 25 & 22.9 & $\begin{array}{c}\text { (Potapov et } \\
\text { al., 2018) }\end{array}$ \\
\hline Lakes Bourget and Annecy (France) & 17.6 & 16.7 & 23.3 & 10.8 & 22.2 & 25.7 & $\begin{array}{c}\text { (Zhong \& } \\
\text { Jacquet, } \\
\text { 2014) }\end{array}$ \\
\hline Lake Donghu (China) & 3.9 & 4.7 & 3.3 & 2.7 & 8.3 & 5.7 & $\begin{array}{c}\text { (Huang, } \\
\text { Cheng \& } \\
\mathrm{Xu}, 2011 \text { ) }\end{array}$ \\
\hline Lake East (China) & 9.8 & 8.3 & 6.7 & 8.1 & 5.6 & 5.7 & $\begin{array}{l}\text { (Wang et } \\
\text { al., 2015) }\end{array}$ \\
\hline Wetland sediment (China) & 25.5 & 20.8 & 3.3 & 18.9 & 2.8 & 2.9 & $\begin{array}{c}\text { (Li et al., } \\
2018)\end{array}$ \\
\hline Borehole water (South Africa) & 2 & 4.2 & 3.3 & 4.1 & 2.8 & 2.9 & $\begin{array}{c}\text { (Mabizela } \\
\& \\
\text { Litthauer, } \\
2016)\end{array}$ \\
\hline Dairy wastewater (Ireland) & - & - & 3.3 & 2.7 & 2.8 & 2.9 & $\begin{array}{c}\text { Knapik \& } \\
\text { Prentice, } \\
\text { 2012) } \\
\end{array}$ \\
\hline Paddy water (China) & - & - & - & 1.4 & 2.8 & 2.9 & $\begin{array}{l}\text { (Zheng et } \\
\text { al., 2013) }\end{array}$ \\
\hline Rimov reservoir (Czech Republic) & 2 & - & 3.3 & 4.1 & - & - & $\begin{array}{l}\text { (Kavagutti } \\
\text { et al., 2019) }\end{array}$ \\
\hline Marine environment & - & - & 3.3 & - & - & - & $\begin{array}{c}\text { (Sandaa \& } \\
\text { Kristiansen, } \\
2016) \\
\end{array}$ \\
\hline Wetland water (China) & 5.9 & 4.2 & - & 1.4 & - & - & $\begin{array}{l}\text { (Zheng et } \\
\text { al., 2013) }\end{array}$ \\
\hline $\begin{array}{l}\text { Sediments of Pearl River Estuary } \\
\text { (China) }\end{array}$ & 2 & 4.2 & - & 1.4 & - & - & $\begin{array}{c}\text { (He et al., } \\
2017)\end{array}$ \\
\hline Lake Kotokel (Russia) & 2 & 4.2 & - & 5.4 & - & - & $\begin{array}{l}\text { (Butina et } \\
\text { al., 2013) }\end{array}$ \\
\hline Lake Limnopolar (Antarctica) & - & - & - & 2.7 & - & - & $\begin{array}{c}\text { (López- } \\
\text { Bueno et } \\
\text { al., 2009) }\end{array}$ \\
\hline Paddy field soil (Japan) & - & - & - & 1.4 & - & - & $\begin{array}{l}\text { (Fujihara et } \\
\text { al., 2010) }\end{array}$ \\
\hline Surface soil of rice field (Japan) & - & - & - & 1.4 & - & - & $\begin{array}{c}\text { (Jia et al., } \\
2007)\end{array}$ \\
\hline
\end{tabular}
1 


\section{Table 4 (on next page)}

Sets of the $g 23$ sequences included in analysis 


\begin{tabular}{|c|c|c|c|}
\hline Isolation source & Localization & Accession number & Reference \\
\hline $\begin{array}{l}\text { Kongsfjorden, } \\
\text { proglacial lake }\end{array}$ & Svalbard, Norway & $\begin{array}{l}\text { JQ996772 - JQ996789 } \\
\text { JQ996716 - JQ996736 }\end{array}$ & Bellas \& Anesio, 2013 \\
\hline Coral colony & $\begin{array}{l}\text { Orpheus Island, } \\
\text { Australia }\end{array}$ & AYH52385 - AYH52406 & Buerger et al., 2018 \\
\hline Hydrothermal vent & East Scotia Ridge & AMN08847 - AMN08920 & $\begin{array}{l}\text { Millard, Pearce \& } \\
\text { Zwirglmaier, } 2016\end{array}$ \\
\hline Chesapeake Bay & USA & AFV99049 - AFV99127 & Jamindar et al., 2012 \\
\hline Lake Baikal & Russia & $\begin{array}{l}\text { ADJ57308 - ADJ57325 } \\
\text { ADA61131 - ADA61153 }\end{array}$ & Butina et al., 2010 \\
\hline $\begin{array}{l}\text { Lake Baikal, } \\
\text { BSOTU }\end{array}$ & Russia & MW307359 -MW307499 & Potapov et al., 2018 \\
\hline Lake Baikal & Russia & QBG58752 - QBG58836 & Potapov et al., 2020 \\
\hline $\begin{array}{l}\text { Lake Annecy and } \\
\text { Bourget, LAB }\end{array}$ & France & AHU87093 - AHU87277 & Zhong \& Jacquet, 2014 \\
\hline Wetland & China & BAL45733 - BAL45791 & Zheng et al., 2013 \\
\hline Lake Kotokel & Russia & AGH68825 - AGH68878 & Butina et al., 2013 \\
\hline Lake Donghu & China & ADI87605 - ADI87650 & $\begin{array}{l}\text { Huang, Cheng \& Xu, } \\
2011\end{array}$ \\
\hline Lake East & China & AKZ31833 - AKZ31924 & Wang et al., 2015 \\
\hline Lake Limnopolar & $\begin{array}{l}\text { Antarctica, } \\
\text { Livingston Island }\end{array}$ & ACZ73354 - ACZ73383 & $\begin{array}{l}\text { López-Bueno et al., } \\
2009\end{array}$ \\
\hline Dairy wastewater & Ireland & AFN85671 - AFN85714 & $\begin{array}{l}\text { Knapik \& Prentice, } \\
2012\end{array}$ \\
\hline Wetland sediments & China & AYN79829 - AYN80090 & Li et al., 2018 \\
\hline $\begin{array}{l}\text { Sediments of the } \\
\text { Pearl River estuary }\end{array}$ & China & ARB48299 - ARB48753 & He et al., 2017 \\
\hline Paddy field & China & BAW82012 - BAW82092 & Li et al., 2019 \\
\hline Paddy field & Japan & BAF91499 - BAF93227 & Wang et al., 2009 \\
\hline
\end{tabular}

